\title{
The Tiny Companion Matters: The Important Role of Protons in Active Transports in Plants
}

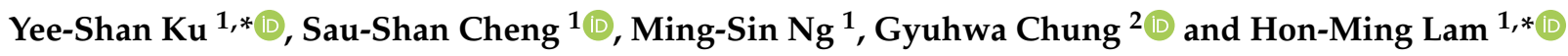 \\ 1 Centre for Soybean Research of the State Key Laboratory of Agrobiotechnology and School of Life Sciences, \\ The Chinese University of Hong Kong, Hong Kong, China; chengsaushan@yahoo.com (S.-S.C.); \\ sammingsin0212@gmail.com (M.-S.N.) \\ 2 Department of Biotechnology, Chonnam National University, Yeosu 59626, Korea; chung@chonnam.ac.kr \\ * Correspondence: ysamyku@cuhk.edu.hk (Y.-S.K.); honming@cuhk.edu.hk (H.-M.L.); \\ Tel.: +852-3943-8132 (Y.-S.K.); +852-3943-6336 (H.-M.L.)
}

Citation: Ku, Y.-S.; Cheng, S.-S.; $\mathrm{Ng}$ M.-S.; Chung, G.; Lam, H.-M. The Tiny Companion Matters: The Important Role of Protons in Active Transports in Plants. Int. J. Mol. Sci. 2022, 23, 2824. https://doi.org/ $10.3390 /$ ijms 23052824

Academic Editor: Masoud

Jelokhani-Niaraki

Received: 29 November 2021

Accepted: 2 March 2022

Published: 4 March 2022

Publisher's Note: MDPI stays neutral with regard to jurisdictional claims in published maps and institutional affiliations.

Copyright: (C) 2022 by the authors. Licensee MDPI, Basel, Switzerland. This article is an open access article distributed under the terms and conditions of the Creative Commons Attribution (CC BY) license (https:// creativecommons.org/licenses/by/ $4.0 /)$.

\begin{abstract}
In plants, the translocation of molecules, such as ions, metabolites, and hormones, between different subcellular compartments or different cells is achieved by transmembrane transporters, which play important roles in growth, development, and adaptation to the environment. To facilitate transport in a specific direction, active transporters that can translocate their substrates against the concentration gradient are needed. Examples of major active transporters in plants include ATPbinding cassette (ABC) transporters, multidrug and toxic compound extrusion (MATE) transporters, monosaccharide transporters (MSTs), sucrose transporters (SUTs), and amino acid transporters. Transport via ABC transporters is driven by ATP. The electrochemical gradient across the membrane energizes these secondary transporters. The $\mathrm{pH}$ in each cell and subcellular compartment is tightly regulated and yet highly dynamic, especially when under stress. Here, the effects of cellular and subcellular $\mathrm{pH}$ on the activities of ABC transporters, MATE transporters, MSTs, SUTs, and amino acid transporters will be discussed to enhance our understanding of their mechanics. The relation of the altered transporter activities to various biological processes of plants will also be addressed. Although most molecular transport research has focused on the substrate, the role of protons, the tiny counterparts of the substrate, should also not be ignored.
\end{abstract}

Keywords: ATP-binding cassette $(\mathrm{ABC})$ transporter; multidrug and toxic compound extrusion (MATE) transporter; monosaccharide transporter (MST); sucrose transporter (SUT); amino acid transporter; detoxification; nutrient transport; stress adaptation; proton gradient; cellular $\mathrm{pH}$

\section{Introduction}

Transporters play important roles in the transport of nutrients, hormones, and metabolites for the purposes of growth, development, and adaptation to stresses. To deliver the substrates in a specific direction, active transporters, which can transport substrates against their concentration gradients, are required. Transmembrane transporters mediate the transport of substrates across biological membranes. The polypeptides of transmembrane transporters contain transmembrane segments (TMSs), which are integrated in the membrane [1]. The segments of the integral membrane proteins embedded in the membrane are called transmembrane domains (TMDs) [2]. Such active transport is often driven by the proton gradient across the cellular/subcellular membrane. Therefore, changes in the cellular/subcellular $\mathrm{pH}$ could regulate the transport activities and determine the direction of transport. In each subcellular compartment, the $\mathrm{pH}$ is highly regulated and yet dynamic. It has been reported that stresses result in changes in cellular $\mathrm{pH}$, which can form part of the stress signal [3]. For example, it was reported that flooding and drought stress induced an increase in the $\mathrm{pH}$ of xylem sap [3]; ionic stress induced an increase in cytosolic $\mathrm{pH}$ and a decrease in vacuolar $\mathrm{pH}$ [4]; fungal infection induced an increase in the $\mathrm{pH}$ of apoplastic sap; and pattern-triggered immunity (PTI) induced a decrease in cytosolic 
$\mathrm{pH}$ [5]. The changes in $\mathrm{pH}$ in different cellular compartments may imply the change in $\mathrm{pH}$ difference as well as the change in electrical potential difference across the biological membrane. Furthermore, the $\mathrm{pH}$ itself could also affect the activity of the transporter and the protonation state of the substrates to be transported. Altogether, these factors influence the transport efficiency and, thus, bring forth the physiological regulations.

In plants, cellular $\mathrm{pH}$ has been reported to be mainly regulated by proton pumps including the plasma membrane ATPase (PM-ATPase), the vacuolar-type ATPase (V-ATPase), the vacuolar pyrophosphatase (V-PPase) [6,7] and $\mathrm{Na}^{+} / \mathrm{H}^{+}$antiporter (NHX) [8]. PMATPase hydrolyzes ATP to release $\mathrm{H}^{+}$, which is then exported out of the cell by PMATPase [9]. Such transport of $\mathrm{H}^{+}$results in the proton gradient and electrical potential gradient across the membrane $[9,10]$. Under salt stress, it has been suggested that the PM-ATPase creates the electrochemical proton gradient to enable the extrusion of $\mathrm{Na}^{+}$ out of the cell or the intrusion of $\mathrm{Na}^{+}$inside the vacuole by NHX [11]. V-ATPase has been known to be responsible for vacuolar acidification and create electrochemical proton gradient across the vacuolar membrane to energize substrate transport in and out of the vacuole $[12,13]$. In addition, V-PPase was suggested to have a higher vacuolar acidification potential compared to V-ATPase and also contribute to energize various transporters, such as $\mathrm{Ca}^{2+} / \mathrm{H}^{+}, \mathrm{Na}^{+} / \mathrm{H}^{+}$and $\mathrm{Zn}^{2+} / \mathrm{H}^{+}$exchangers and phosphate transporter, at the vacuolar membrane [14]. The $\mathrm{pH}$ of various cellular compartments is associated with the activities of proton pumps and transporters that transport substrates in exchange of $\mathrm{H}^{+}$.

Phytohormone transporters, alkaloid transporters, ion and ion chelator transporters, sugar transporters, and amino acid transporters are common active transporters in plants. Examples of phytohormone transporters, alkaloid transporters, and ion and ion chelator transporters include ATP-binding cassette (ABC) transporters and Multidrug Additionally, Toxic compound Extrusion (MATE) transporters, while examples of sugar transporters include MonoSaccharide Transporters (MSTs) and SUcrose Transporters (SUTs). These transporters have been reported to play important roles in various biological processes including cellular detoxification, nutrient transport, and stress adaptation. Previous reports have largely focused on the transport of substrates such as metabolites, sugars, and amino acids by these transporters. However, considering the mechanics of the transport activities, the protons required in exchange of these substrates also deserve the same attention. The awareness of the role of protons, and therefore $\mathrm{pH}$, in transport activities will bring forth a more comprehensive understanding of these transporters.

\section{Phytohormone Transporters}

ABC transporters and MATE transporters are the two major types of multidrug transporters that transport various substrates including phytohormones, alkaloids, ion, and ion chelators [15].

\subsection{Overview of $A B C$ Transporters}

The ATP-binding cassette $(\mathrm{ABC})$ transporters belong to one of the largest superfamilies of transporters and are present in many organisms ranging from prokaryotes to human [16]. Driven by the free energy change associated with ATP hydrolysis, ABC transporters have been reported to drive the export or import of various substrates across biological membranes against the electrochemical gradient [17]. Based on the protein structure, $A B C$ transporters can be classified into three structural types: the full transporter having two TMDs and two nucleotide-binding cytosolic domains (NBDs), the half transporter having one TMD and one NBD, and the third type of transporter having no TMD and two NBDs [18]. Half transporters could dimerize to form virtual full transporters [18]. The NBD of $A B C$ transporters consists of the signature LSGGQ motif, which enables them to be distinguished from other ATPases [18]. Besides the signature LSGGQ motif, the NBD also contains other conserved motifs including Walker A, Q-loop, Walker B, D-loop, and switch H-loop [18]. The Walker A and B motifs are important for ATP binding by forming 
a P-loop, while the residues of Q-loop and H-loop interact with the $\gamma$-phosphate of the ATP [18].

In plants, $\mathrm{ABC}$ transporters were first identified as being involved in cellular detoxification by mediating the storage of xenobiotics inside the vacuole [19]. They have subsequently been reported to be involved in other biological processes such as the regulation of growth and development, tolerance to abiotic and biotic stresses, and nutrient uptake [20]. Terrestrial plants contain more $\mathrm{ABC}$ transporter genes in their genomes than other living organisms [21]. These transporters can facilitate the transportation of diverse substrates including hormones such as auxins and abscisic acid (ABA), and secondary metabolites such as flavonoids, reactive oxygen species (ROS), and lipid molecules $[20,22,23]$. Thus, ABC transporters play crucial roles in the development and survival of plants by translocating different molecules under diverse conditions. The subcellular localizations of ABC transporters in various membranes, including the membrane of peroxisome, mitochondrion, vacuole, chloroplast, and plasma membrane, have been reported [24-28].

\subsubsection{The Deprotonation of Auxin Molecules in Cytoplasm Implies the Need for} Active Transporters

Auxin molecules can migrate by mass flow in the vascular system or being transported from cell to cell [29]. In the cytoplasm where the $\mathrm{pH}$ is near neutral, most of the indoleacetic acid (IAA) molecules exist in the anionic form, which is not favorable for diffusion across the plasma membrane [29]. Therefore, the transport of ionized auxin molecules across the membrane would need active auxin transporters [29].

It was reported that $\mathrm{ABCB}$ transporters are associated with the active transport of auxin driven by ATP hydrolysis [30]. $A B C B$ s are mainly expressed in the leaf and root meristem and are related to the transportation of auxin in the apoplast [15]. AtABCB1 and $A t A B C B 19$ are $A B C$ transporters mediating intracellular auxin transport and were reported to be involved in anther development [31]. The Arabidopsis double knockout mutant of $a b c b 1 a b c b 19$ showed reduced apical dominance, dwarfism, short hypocotyl, and poor fertility [32]. It was also reported that the direction of transport of IAA mediated by AtABCB4 could be reversed depending on the relative IAA concentration [33]. Although the substrate, IAA, was transported down the concentration gradient, such transport still had to be mediated by AtABCB4 [33]. However, the structural basis for such reverse of substate transport direction by the transport has remained unclear. In Oryza sativa, under salt stress, it was found that the $O S A B C B$ genes in leaf and root had differential expression responses towards the stress [34]. Under salt stress, a finetune of auxin levels in various plant tissues is needed to archive the balance of different biological processes such as biosynthesis and signal perception [35]. From these examples, it could be deduced that the deprotonation of auxin under stress is coupled with the regulated expression of $A B C$ transporters to archive the finetune of auxin transports.

\subsubsection{The Deprotonation of ABA Molecules in the Apoplast Implies the Need for} Active Transporters

ABA is involved in the signaling of both abiotic and biotic stresses [36]. One of the major roles of ABA is the regulation of stomatal opening [36]. The possible active transport of ABA between cells and between tissues has been suggested [37-39]. The ABA molecule is negatively charged in the cytosol where the $\mathrm{pH}$ is near neutral. During drought stress, the $\mathrm{pH}$ in the apoplast increases [40]. At a higher $\mathrm{pH}, \mathrm{ABA}$ molecules undergo further proton dissociation. The negative charge of the ABA molecules implies the need for active ABA transport across membranes. AtABCG25 is an ABA exporter involved in the intercellular signaling pathway [41]. It is mainly expressed in vascular tissues and localized in the plasma membrane, suggesting the role of AtABCG25 in ABA export [41]. atabcg25 knockout mutants exhibited enhanced ABA-sensitive phenotypes at the early growth stage compared to the wild-type [41]. On the other hand, other ABC transporters could also be ABA importers. For example, AtABCG40 is an ABA uptake transporter in the plasma membrane. Such function of AtABCG40 was demonstrated in both yeast and tobacco BY2 
cells ectopically expressing AtABCG40 [42]. Compared to the wild-type, atabcg40 mutants had a slower uptake of ABA into the protoplast and a slower rate of stomatal closure under ABA treatment [42]. Furthermore, in wheat, Lr34, a PDR-type ABCG transporter, was found to be an ABA transporter. The ectopic expression of the Lr34res allele from a rice blast-resistant wheat cultivar improved the accumulation of $\mathrm{ABA}$ and enhanced the tolerance of rice to rice blast [43]. These examples show the important roles of $A B C$ transporters in transporting $\mathrm{ABA}$ between cells, especially when $\mathrm{ABA}$ molecules are further deprotonated under stress.

\subsection{Overview of MATE Transporters}

Multidrug and toxic compound extrusion (MATE) transporters are antiporters that transport various molecules across a membrane in exchange for sodium ion $\left(\mathrm{Na}^{+}\right)$or proton $\left(\mathrm{H}^{+}\right)$[44]. The movement of $\mathrm{Na}^{+}$or $\mathrm{H}^{+}$across the membrane results in an electrochemical gradient that drives the transport of the substrates, which could be macromolecules or ions, in the opposite direction [44]. Most eukaryotic MATE transporters utilize $\mathrm{H}^{+}$while prokaryotic MATE transporters can use either $\mathrm{Na}^{+}$or $\mathrm{H}^{+}$for this purpose [44]. In plants, MATE transporters typically consist of 12 transmembrane domains and have been reported to be located at membrane structures including the plasma membrane, vacuolar membrane, mitochondrial membrane, chloroplast envelope, and the surface of small vesicles [45].

The Phytohormone Transport Activities of MATE Transporters Could Be Dependent on $\mathrm{pH}$ or Electrochemical Proton Gradient

AtDTX50 (detoxification efflux carrier) was reported to be a plasma membranelocalized MATE-type protein for ABA efflux [46]. AtDTX50 is mainly expressed in vascular tissues and guard cells where ABA is synthesized [46]. Under drought stress, the $\mathrm{pH}$ in xylem sap was found to increase from 6.1 to 6.7 [47]. Among pH 6, 7, and 8, AtDTX50 was found to be most active at $\mathrm{pH} 7$ [46]. It therefore appears reasonable that, during drought, the xylem sap $\mathrm{pH}$ becomes closer to $\mathrm{pH} 7$ to maximize the ABA-export activity of AtDTX50. However, from the mechanical perspective, it is not clear why the ABA-exporting function of AtDTX50 was highest at $\mathrm{pH} 7$. Considering the near neutral cytosolic $\mathrm{pH}$, when the $\mathrm{pH}$ of the medium was lower than 7 , the proton gradient as well as the electrical potential difference across the cell membrane increased. However, such increases did not appear to enable an increased ABA export in exchange of the influx of $\mathrm{H}^{+}$from the medium. It is possible that the $\mathrm{pH}$ itself, besides the $\mathrm{pH}$ gradient across the membrane, has effects on the protein function. Since MATE is not the sole transporter of ABA, it is possible that other transporters could complement the ABA transport when one transporter is not working at its optimal capacity.

Besides ABA, MATE transporter has also been reported to transport salicylic acid (SA). ENHANCED DISEASE SUSCEPTIBILITY5 (EDS5) was reported to be a chloroplast envelope-localized MATE-type protein that transports SA from chloroplast to cytoplasm [48]. The eds5 mutant was formerly known as the sid (SA induction deficient) mutant $[49,50]$. It was found that when the proton gradient was destroyed by nigericin or m-chlorophenyl hydrazone (CCCP), the SA-exporting activity of EDS5 was disrupted [48]. Therefore, it was suggested that the SA-exporting activity of EDS5 is dependent on the electrochemical gradient generated by protons [48]. The expression of EDS5 was induced by Pseudomonas syringae [51]. Upon pathogen infection, in PTI, cytosolic acidification occurs [5]. It would therefore be reasonable to speculate that, upon pathogen infection, the SA-exporting activity of EDS5 is enhanced. Altogether, the induced expression of EDS5 and the enhanced exporting activity of the protein promote the resistance to the pathogen.

\section{Alkaloid Transporters}

\subsection{ABC Transporter for the Storage of Alkaloids}

Besides phytohormones, $\mathrm{ABC}$ transporter is also able to transport alkaloids. $\mathrm{ABC}$ transporters play an important role in vacuolar sequestration, which is an important 
process for minimizing the effects of toxic compounds and heavy metals [52,53]. Various secondary metabolites, including terpenoids, alkaloids and phenolics, are employed for defense purposes in plants [54]. However, the accumulation of these compounds can be toxic. Therefore, in plant cells, the secondary metabolites are either stored as the non-toxic precursors in the vacuole or exported out of the cell [55]. Berberine, a member of the alkaloid family, which is one of the largest groups of secondary metabolites in plants, was reported to accumulate in the rhizome of Coptis japonica, as an antimicrobial compound [56]. It was reported that CjMDR1 (Coptis japonica multidrug resistance 1) mediates the transport of berberine. CjMDR1 is expressed in the xylem tissue and encodes a multidrug-resistance protein (MDR)-type $\mathrm{ABC}$ transporter to facilitate the transport of berberine from the root to the rhizome [56].

\subsection{MATE Transporter for the Storage of Alkaloids}

Besides exporting substrates from the cell, MATE transporters have also been shown to mediate substrate influx into organelles such as vacuoles. In Nicotiana tabacum, $\mathrm{Nt}$ JAT1 (Nicotiana tabacum jasmonate-inducible alkaloid transporter 1) was reported to be a MATE-type antiporter that mediates the influx of nicotine into the vacuole in exchange of $\mathrm{H}^{+}$[57]. The uptake function of Nt-JAT1 was found to be facilitated by F0F1-ATPase (F-ATPase), the $\Delta \mathrm{pH}$ generator in the membrane, and was reduced by the dissipation of the $\mathrm{pH}$ gradient [57]. The lower $\mathrm{pH}$ inside the vacuole compared to the cytosol enabled the export of $\mathrm{H}^{+}$from the vacuole. In this case, the nicotine influx into the vacuole resulted in the increase in cytosolic $\mathrm{H}^{+}$.

\section{Ion and Ion Chelator Transporters}

\subsection{ABC Transporters for the Detoxification of Heavy Metal}

$A B C$ transporters have also been reported to be involved in the detoxification of various toxic heavy metals such as cadmium $(\mathrm{Cd})$, mercury $(\mathrm{Hg})$, and aluminum $(\mathrm{Al})$. In Arabidopsis, compared to the wild-type, the double knock-out mutant $a b c c 1 a b c c 2$ was hypersensitive to arsenic (As) and had reduced vacuolar uptake of $\mathrm{As}(\mathrm{III})-\mathrm{PC}_{2}$ and apoPC 2 [26]. However, the overexpression of $A t A B C C 1$ alone could not promote the tolerance to As [26], unless it was co-overexpressed with AtPCS1 (PhytoChelatin (PC) Synthase) [26]. Using yeast as the model, it was shown that the ectopic expression of $A t A B C C 1$ or $A t A B C C 2$ mediated the microsomal uptake of $\mathrm{PC}_{2}$-As more efficiently than that of apo- $\mathrm{PC}_{2}$ [26]. It was therefore concluded that AtABCC1 and AtABCC2 are the transporters of PC and PC conjugates and mediate the uptake of PC-conjugated As into the vacuole for detoxification [26]. In another report, $A t A B C C 1$ and $A t A B C C 2$ were shown to mediate the tolerance to $\mathrm{Cd}$ and $\mathrm{Hg}$ [58]. In Arabidopsis, the double knock-out mutant abcc1abcc2 was also hypersensitive to $\mathrm{Cd}(\mathrm{II})$ and $\mathrm{Hg}(\mathrm{II})$, and was demonstrated to be impaired in the vacuolar sequestration of Cd [58]. In addition, AtABCC1 and AtABCC2 enhanced the tolerance of PC-producing yeast to $\mathrm{Hg}(\mathrm{III})$ [58]. In rice, the ortholog of AtABCC1 and AtABCC2, OsABCC1, was also demonstrated to be a transporter that mediates the uptake of PC-As into the vacuole [59]. $\mathrm{ABC}$ transporters involved in mediating the tolerance to other heavy metals such as $\mathrm{Al}$ have also been reported and reviewed [60].

\subsection{The Ion/Ion Chelator Transport Activities of MATE Transporters Are $p H$ Dependent}

Using Xenopus oocytes as the model, it was shown that a decrease in the $\mathrm{pH}$ of the medium favored the SbMATE (Sorghum bicolor MATE)-mediated efflux of citrate from the oocytes [61]. Similarly, the Arabidopsis MATE transporters, TT12 [62], FRD3 [63], and AtDTX1 [64], were also found to be substrate $/ \mathrm{H}^{+}$antiporters. $\mathrm{H}^{+}$-ATPase was suggested as the provider of $\mathrm{H}^{+}$for MATE transporters in exchange for their substrates [65]. When under aluminum $(\mathrm{Al})$ toxicity stress, the concerted activities of plasma membrane-bound $\mathrm{H}^{+}$-ATPase and a MATE transporter mediated the efflux of citrate and played a role in maintaining a stable cytosolic $\mathrm{pH}$ [65]. The Al-induced extrusion of citrate has been known as a strategy to enhance tolerance to $\mathrm{Al}$ toxicity. Under neutral $\mathrm{pH}$ in the cytosol, $\mathrm{H}^{+}$is 
dissociated from citric acid from the TCA cycle [65]. The $\mathrm{H}^{+}$is then transported out of the cell by $\mathrm{H}^{+}$-ATPase [65]. The remaining citrate is then exported from the cell by MATE, possibly with the transport of $\mathrm{H}^{+}$back into the cytosol [65]. The extruded citrate molecules chelate $\mathrm{Al}$ cations to prevent $\mathrm{Al}$ cations from entering the cell [66]. This process is likely to result in the increase in cytosolic $\mathrm{H}^{+}$level. It was speculated that this drop in cytosolic $\mathrm{pH}$ may be related to the $\mathrm{pH}$ regulation in the cytosol and the balancing of charges for secondary ion transports [65].

The MATE transporters DTX33 and DTX35 in Arabidopsis were reported to be tonoplast-localized MATE-type proteins that mediate $\mathrm{Cl}^{-}$influx into the vacuole and regulate the vacuolar turgor [67]. The $d t x 33 / d t x 35$ double mutant is impaired in stomatal opening and is more tolerant to drought. Although DTX33 and DTX35 were demonstrated to function as ion channels with the measured reversal potentials in agreement with the theoretical Nernst potentials at different $\mathrm{pH}$ and dependent on the $\mathrm{Cl}^{-}$concentration, it was also demonstrated that their activities were dependent on vacuolar $\mathrm{pH}$ [67]. Among vacuolar $\mathrm{pH}$ 5, 6, and 7, DTX33 and DTX35 had the highest activities at pH 5 [67]. However, whether the change in transport activity was due to the $\mathrm{pH}$ itself or the change in $\mathrm{pH}$ gradient, which means the change in proton gradient as well as electrical potential gradient, remains unclear.

The above examples show that the export of substrates out of the cell and the import of substrate into the vacuole by MATE transporters could mediate the upregulation of the cytosolic $\mathrm{H}^{+}$concentration $[57,65]$. On the other hand, the differential $\mathrm{H}^{+}$concentrations in different cellular compartments, which result in the $\mathrm{pH}$ gradient across the biological membrane where the MATE transporters are localized, regulate the activities of the transporters. Under stress, the fluctuation of cellular $\mathrm{pH}$ possibly plays a role to regulate the activities of MATE transporters.

\section{Sugar Transporters}

\subsection{Classification and Structural Properties}

In plants, MonoSaccharide Transporters (MSTs), SUcrose Transporters (SUTs; or SUCs, SUcrose Carriers), and Sugars Will Eventually be Exported Transporters (SWEETs) are the three major types of sugar transporters $[68,69]$. SUTs and MSTs belong to the major facilitator superfamily (MFS), which has the characteristic 12 transmembrane domains (TMDs), in the form of $6 \mathrm{~N}$-terminal TMDs connected to 6 C-terminal TMDs via a cytosolic loop [68,70,71]. Despite having similar architectures, SUTs and MSTs could be differentiated from each other by the different domain structures [68]. On the other hand, SWEETs have seven TMDs and are characterized by an MtN3/saliva domain [68]. In terms of the transport mechanism, MSTs and SUTs are proton/sucrose symporters [72-74], while SWEETs are reported to be uniporters of sugars [72,73]. In the following sections, only MSTs and SUTs, whose functions are $\mathrm{H}^{+}$-dependent, will be discussed.

\subsection{The SUT Family}

In photosynthetic cells, sucrose is derived from the photosynthetically fixed carbon and is the major form of sugar transported via the phloem to other tissues [75,76]. SUTs are $\mathrm{H}^{+}$/sucrose symporters involved in loading sucrose into the phloem against the concentration gradient and are driven by the proton motive force across the plasma membrane of the sieve element-companion cell complex (SE-CCC) [77].

\subsubsection{The Activities of SUTs Are $\mathrm{pH}$-Dependent}

The $\mathrm{pH}$ dependence of SUT activities has been reported in various species. For example, in Arabidopsis, AtSUC4 was reported to be a proton/sucrose symporter localized in the vacuole membrane [78]. The proton motive force was suggested to be provided by the pumping of cytosolic protons into the vacuole by V-type ATPases and V-PPases [78]. Using yeast as the model, the proton-coupled and $\mathrm{pH}$-dependent uptake of sucrose mediated by AtSUT4 was demonstrated [79]. Further experiments showed that AtSUC4 could act as 
a $\mathrm{H}^{+}$/ sucrose antiporter or symporter depending on the $\mathrm{pH}$ difference between vacuole lumen and the medium outside [78]. When the vacuole lumen was more acidic than the medium outside, sucrose was imported into the vacuole with the export of $\mathrm{H}^{+}$from the vacuole; when the medium outside the vacuole was more acidic, sucrose was transported together with proton into the vacuole [78]. Such switch of antiporter/symporter activity is illustrated in Figure 1. Similar bidirectional transport of sucrose was demonstrated using the phloem-localized ZmSUT1 [80]. The sucrose $/ \mathrm{H}^{+}$symporter activity of ZmSUT1 was demonstrated to be $\mathrm{pH}$-dependent [80]. It was suggested that both the sucrose gradient and the proton motive force determine the sucrose/proton symport direction [80].

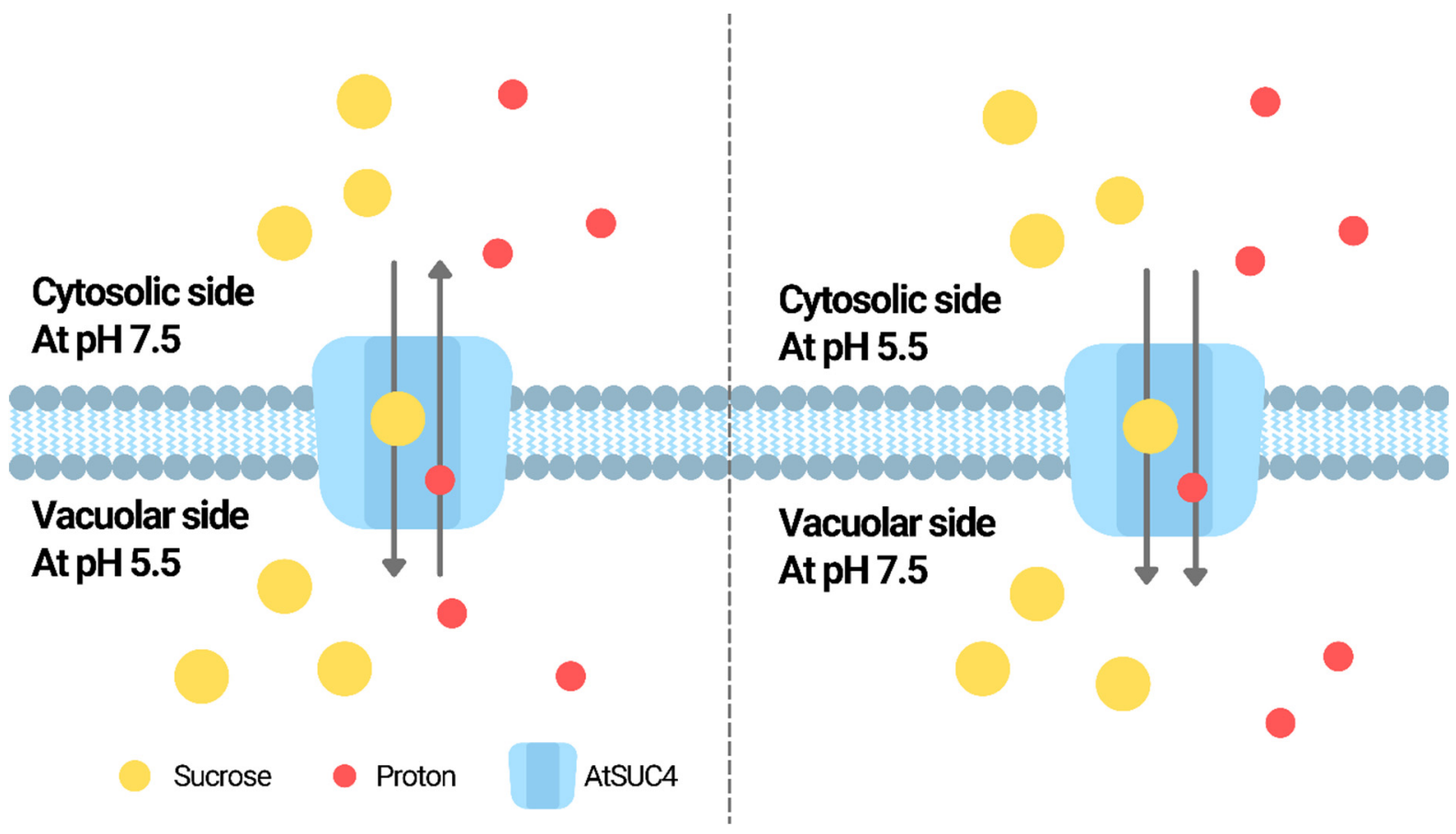

Figure 1. The switch of antiporter/symporter activity of AtSUC4. When the vacuole lumen was more acidic than the medium outside, AtSUC4 mediates the import of sucrose into the vacuole with the export of $\mathrm{H}^{+}$from the vacuole; when the medium outside the vacuole was more acidic, AtSUC4 mediates the transport of sucrose together with proton into the vacuole [78].

\subsubsection{The Role of Sucrose Transport during Stress-Induced Cellular $\mathrm{pH}$ Fluctuations}

Atsuc4 mutants were found to be more sensitive to stresses including salt, osmotic, cold, and ABA treatments compared to the wild-type [81]. Probably due to the impaired sugar distribution, these mutants were found to have higher and lower sucrose, fructose and glucose in the shoots and roots, respectively, compared to the wild-type [81]. The ABA-induced expressions of stress-responsive genes, including ABA-responsive element binding factors (ABFs) and the genes upstream or downstream to ABFs, were inhibited in Atsuc4 mutants [81]. Although the detailed mechanism remained unclear, it was suggested that AtSUC4 is involved in the crosstalk between ABA signaling and sucrose signaling [81]. The accumulation of sucrose in the root is agriculturally important for those crops that are harvested for their edible roots. In sweet potato (Ipomoea batatas), similar to AtSUC4, IbSUT4 was found to regulate the accumulation of sucrose in the root and ABA signaling under stress [82]. The overexpression of IbSUT4 in Arabidopsis reduced the sucrose level in the leaf but improved the sucrose level in the root under salt stress [82]. This is possibly the result of a drop in cytosolic $\mathrm{pH}$ induced by salt stress [83], which reduced the sucrose export from the vacuole by SUT4.

The Phaseolus vulgaris SUT1.1, when expressed in transgenic yeast, was found to have a higher transport activity when the $\mathrm{pH}$ of the medium was more acidic [84]. The 
tonoplast- and plasma membrane-localized PvSUT1.1 was reported to be a sucrose-proton co-transporter that is probably involved in the export of sucrose from the leaf through the phloem [84]. In the same study, the expression of PvSUT1.1 was found to be repressed in the leaf upon heat stress [84]. Since the export of sucrose from the leaf is important for heat tolerance, the heat stress susceptibility of $P$. vulgaris was therefore hypothesized to be associated with the repression of PvSUT1.1 under high temperature [84]. However, under high temperature in the leaf, $\mathrm{H}^{+}$can leak through membranes [85]. Although not discussed in this study, such proton leaks in the cytosol may influence the transport activity of SUT in the tonoplast and plasma membrane. The net effect on the export of sucrose from the cell is unknown. To explain the SUT activity under stress, more mechanistic considerations, other than transcriptional controls, will be needed.

It has been widely accepted that SUTs are responsible for phloem loading. However, the analyses of expression data, including microarray, RNAseq, and quantitative PCR, from 167 experiments on various plant species showed that the effects on SUT expressions by factors such as photosynthetic rate, light level, and $\mathrm{CO}_{2}$ concentration are limited [86]. It was speculated that when the photosynthetic rate is increased, the existing SUT proteins may already have enough capacity to increase phloem loading without the need to increase their transcript levels [86]. Other regulatory mechanisms, such as differential intracellular localization and protein dimerization, were suggested [86]. Mechanistically, the changes in proton distribution under different environmental conditions could also potentially alter the SUT activity. Using Amaranthus caudatus and Vicia faba as the models for $\mathrm{C}_{4}$ and $C_{3}$ plants, respectively, despite different kinetics and extents, the $C_{4}$ and $C_{3}$ plants both exhibited light-dependent cytosolic alkalization and vacuolar acidification [87]. Such alkalization and acidification peaked when the photosynthetic apparatus was maximally energized under high energy flux rates in the absence of $\mathrm{CO}_{2}$ [87]. Under such conditions, it is likely that the SUT activity will be affected. Therefore, the expression levels of SUTs under different environmental conditions could not sufficiently explain the regulation of the SUT function.

\subsection{The MST Family}

\subsubsection{Classification and Structural Properties}

Based on the protein sequences, MSTs can be further classified into several clades, including the STP, HXT, PLT-VGT, SBG-GLT-GLUT1, ERD6-like, and TMT clades [74]. Monosaccharides including glucose, fructose, galactose, mannose, and xylose are possible substrates of MSTs [88].

Based on the crystal structure of STP10 from A. thaliana that has recently been resolved $[89,90]$, it was suggested that the protein's affinity for sugar is mainly due to the $\mathrm{N}$-terminal domain and the Lid domain of the protein, while the substrate specificity is mediated by the C-terminal domain, which interacts with specific hydroxyl groups of the substrate [89]. At the apoplast, which is acidic, protonation of the Asp42 residue occurs and finetunes the protein structure to enhance the binding affinity to the substrate [89]. The subsequent unloading of glucose then enables a modification in the protein structure, which results in the release of the proton from Asp42 [90]. Since the important functional domains for the proton-coupled substrate transport are conserved among STPs, it was suggested that this transport model explains the general mechanism of action of the transporter [89,90].

\subsubsection{The Activities of MSTs Are $\mathrm{pH}$-Dependent}

In A. thaliana, AtPLT5 (polyol transporter 5) was reported to be a plasma membranelocalized MST-like protein that mediates the transport of sorbitol, glucose, galactose, ribose, xylose, mannitol, glycerol, and inositol [91]. Using transgenic Xenopus oocytes as the model and glucose and glycerol as substrate examples, the transport activity of AtPLT5 was demonstrated to be $\mathrm{pH}$-dependent [91]. Maximal transport activity was demonstrated at pH 5.5 [91]. At pH 6.5, the transport activity was reduced; at $\mathrm{pH} 7.5$, there was no transport activity [91]. When the extracellular $\mathrm{pH}$ was brought back to 5.5, the transport activity 
resumed [91]. AtPLT5 has a broad spectrum of substrates and is found to be expressed in various tissues [91]. Therefore, it is proposed that AtPLT5 is possibly involved in the retrieval of sugars from the apoplast [91]. The $\mathrm{pH}$-dependent sugar/proton symporter activity of STPs was also reported in apple (Malus domestica) [92]. MdSTP13a was reported to be the transporter of both hexose and sucrose competitively to provide the sugars for pollen tube growth [92]. Using transgenic yeast as the model, optimal glucose or sucrose uptake by MdSTP13a was established at pH 6 [92]. An increase or decrease in the $\mathrm{pH}$ resulted in declined transport activity [92]. Different STPs have different optimal pH for their transport activities. For example, DgSTP1 from Datisca glomerata has the optimal pH for transport activity at $\mathrm{pH} 4.5$ [93]. In plants, the transport of sugars is a major strategy to distribute or store nutrients [77]. Since different cellular compartments have different $\mathrm{pH}$, understanding the $\mathrm{pH}$ dependence of the activities of sugar transporters is essential for the interpretation of the biological functions.

\subsubsection{Paralogs of MSTs Have Differential Expression Patterns to Serve Different Functions}

In $A$. thaliana, AtSTP1 was found to have a consistently high expression level in both the root and leaf among all 14 of the STPs identified, under normal conditions [94]. However, in the root, the expression of AtSTP13 was highly inducible by salinity and ABA treatment [94]. Although the expression of ATSTP1 in the root was also induced by salinity, the fold change is much less than that of AtSTP13 [94]. Both stp1 and stp13 mutants had reduced abilities to uptake glucose and fructose, while stp 1 also had reduced galactose uptake [94]. After salt treatment, the leak of glucose from the stp13 mutant was enhanced [94]. Based on the expression data and the sugar flux data, it was suggested that AtSTP13 mediates the reabsorption of monosaccharides leaked from damaged cells under salt stress while AtSTP1 is the major contributor of monosaccharide uptake under normal conditions [94]. Such differential functions of STPs in the same species are in line with another expression study on STPs in O. sativa. In this study, the expressions of STPs were found to be responsive to stresses including cold, high temperature, and submergence [95]. However, the patterns of expression upon the same stress were diverse among various STPs, which also had different expression patterns in different tissues [95].

\section{Amino Acid Transporters}

Plants can absorb inorganic and organic nitrogen from the environment via the root system [96]. In soil, inorganic nitrogen is usually found in the forms of nitrate and ammonium, while organic nitrogen usually exists in the forms of free amino acids, urea, and short peptides [97]. The uptake of nitrogen-containing molecules by plants is mediated by the respective transporters of these molecules, especially amino acid transporters, which have been known to play a major role in distributing nitrogen throughout the whole plant [98]. Amino acid accumulation and signaling have been suggested to play important roles in stress responses.

\subsection{Classification and Structural Properties}

Amino acid transporters are found in diverse plant species. They are categorized into three major families: the Amino acid Transporter Family (ATF) (which is also known as the Amino Acid/Auxin Permease (AAAP) family), the Amino acid-Polyamine-organoCation (APC) family and the Usually Multiple Acids Move In and out Transporter family (UMAMIT) [99-102]. The ATF family consists of eight subfamilies: general Amino Acid Permeases (AAPs), Lysine and Histidine Transporters (LHTs), Proline Transporters (ProTs), $\gamma$-Aminobutyric acid Transporters (GATs), aromatic and neutral amino acid transporters, indole-3-acetic acid transporters (AUXs), amino acid transporter-like proteins and Vesicular Aminergic-Associated Transporters (VAATs). The APC family consists of three subfamilies: Cationic Amino acid Transporters (CATs), Amino acid/Choline Transporters (ACTs), and Polyamine $\mathrm{H}^{+}$-Symporters (PHSs). Members of the ATF family and the APC family usually share similar transport activities and protein structures. These transporters usually function 
by one of these mechanisms: solute-cation symport, solute-solute antiport, or facilitated diffusion at the plasma membrane [103], and they have a common protein structure with 10-14 TMDs $[103,104]$. UMAMITs were more recently identified compared to the ATF and APC families. These transporters belong to the nodulin-like gene family, functioning as the bidirectional facilitator for amino acid transport [102,105].

\subsection{Amino Acid Transporters Are Driven by Proton Motive Force}

Amino acid transporters act as secondary active transporters, with the specific amino acid being transported coupled to the proton motive force generated by the primary active $\mathrm{H}^{+}$-pumping complex featuring a proton-pumping ATPase at the membrane [9,100,106-108]. The majority of amino acid transporters characterized in plants are proton-amino acid symporters [9,100,106-108]. During amino acid import, a transient alkalization of the extracellular medium was observed [106]. In transgenic yeasts expressing Arabidopsis amino acid transporter genes such as $A A P 3, A A P 4$, or $A A P 5$, the proline uptake rate was increased when the external $\mathrm{pH}$ was made to decrease. In other words, the higher external $\mathrm{H}^{+}$concentration leads to a stronger transportation driving force for the uptake of the amino acid [108]. The requirement for the driving force provided by the proton gradient was further evidenced by the amino acid transport being abolished upon the addition of the protonophore, CCCP, a compound used for disrupting the proton gradient across the mitochondrial membrane by increasing its permeability to protons [106,108-111].

\subsection{The Expressions of Amino Acid Transporters Are Stress-Responsive}

Changes in the expressions of amino acid transporters were reported under abiotic stresses such as salt and water stress in Arabidopsis, rice, wheat, and barley [112-116]. Spatiotemporal differences in the induction patterns of different amino acid transporters upon stress were often observed within the same plant species or among their functional homologs. The Hordeum vulgare (barley) proline transporter, HvProT, was suggested to be crucial in transporting proline to the root tip region upon salt stress [116]. The Triticum aestivum (wheat) proline transporter 3, TaProT3, was upregulated in the root under salt stress whereas TaProT1 and TaProT2 were downregulated [115]. Through genome-wide identification and evolutionary expression analyses on wheat amino acid transporters, numerous stress- and hormone-responsive cis-regulatory elements were found within the promoter regions of the amino acid transporter genes [117]. Similar cis-regulatory element analyses were conducted between Brassica napus (rapeseed) and Arabidopsis, and the results were consistent with previous research [117], where multiple possible transcription factor recognition sites were discovered in the promoter regions of these transporter genes [118]. Based on the gene expression data, both TaAATs and BnAAPs responded differently to different abiotic stresses, suggesting the involvement of different interconnected regulatory networks of transporters in response to specific stresses [117,118].

\subsection{Amino Acids as Osmolytes and Their Involvement in Ion Transport Mechanisms during Stress Responses}

The accumulation of proline is widely known to protect plants from water-related stresses such as salinity, drought, and freezing [119]. The high solubility of proline and low inhibitory effect on seed germination make it a good candidate as a non-toxic osmolyte. One of the toxic effects of salt stress is the mineral nutrient imbalance brought forth by the over-accumulation of $\mathrm{Na}^{+}$and $\mathrm{Cl}^{-}$, and the reduced levels of other essential ions such as $\mathrm{K}^{+}$and $\mathrm{Ca}^{2+}$ [120]. In different plant species, including Olea europaea [121] and Cucumis sativus [122], it was reported that the application of proline promoted salt tolerance. In $O$. europaea, it was shown that proline treatment reduced the level of $\mathrm{Na}^{+}$but enhanced the level of $\mathrm{Ca}^{2+}$ in the leaf under salt treatment [121]. In C. sativus, it was shown that proline treatment reduced the level of $\mathrm{Cl}^{-}$in the leaf under salt treatment [122]. Exogenous proline and glycine betaine application were also reported to relieve the inhibition on both root and shoot growth of barley seedlings due to $\mathrm{NaCl}$ [123]. These observations suggest a possible 
involvement of amino acids, such as proline and glycine betaine, in the ion transportation mechanism.

\subsection{Amino Acid Accumulation and Salicylic Acid (SA) Signaling}

Plants carry a readily utilizable form of nitrogen. It is conceivable that the amino acid composition in plants was one of the determinants of plant-pathogen interactions. The importance of amino acid transporters in sustaining pathogen growth is not surprising. For example, there are a large number of transporter protein-encoding genes in the Psuedomonas syringae genome [124]. The cellular concentrations of amino acids, the uptake of inorganic nitrogen, and the relocation of amino acids might contribute to the plant's susceptibility towards the pathogen $[125,126]$. It has been suggested that amino acid-derived signaling can regulate SA accumulation and signaling [127,128]. A broad-specificity, high-affinity AAP homolog, Lysine Histidine Transporter 1 (LHT1), expressed in the rhizodermis and mesophyll in Arabidopsis [111] was related to the pathogen susceptibility exhibited by the plant. The knockout Arabidopsis mutant $l h t 1$ had reduced susceptibility to the hemibiotrophic pathogen, P. syringae [125]. It was hypothesized that the cellular redox status is modulated by nitrogen metabolism, where glutamine deficiency plays an important role in enhancing the defense responses of $l h t 1$ plants. By studying the accumulation patterns of $\mathrm{H}_{2} \mathrm{O}_{2}$ and $\mathrm{NO}$ in the mesophyll and the spatial expression patterns of the pathogen-induced LHT1, it was suggested that LHT1 helped to maintain a low reactive oxygen species (ROS) level by keeping the glutamine level high. As a result, the low ROS level hindered the activation of SA-mediated defense responses [125].

In another study, Arabidopsis overexpressing AtCAT1 (Cation Amino acid Transporter 1 ) incorporated lysine at a higher rate and was more resistant to $P$. syringae compared to the wild-type and the cat1 mutant [126]. In the AtCAT1 overexpressor, the resistance to the bacterial pathogen $P$. syringae was enhanced with an increased SA level in the leaves [126]. Therefore, the expression levels of amino acid transporters might affect biotic stress responses by manipulating the cellular amino acid concentrations $[125,126]$.

\subsection{Amino Acid Transporters Are Involved in the Regulation of Cellular $p H$ and Rhizospheric $p H$}

Although amino acids usually carry charges and their transportation across membranes is often coupled with protons, there was no significant direct correlation among amino acid concentrations, transport, and cellular $\mathrm{pH}[97,129]$. Nevertheless, there have been reports of amino acid assimilation and transportation altering $\mathrm{pH}$ homeostasis in plants. Ammonium, nitrogen, and nitrate assimilation produce protons that affect the cellular $\mathrm{pH}$ [130]. Aspartic acid and glutamic acid are suggested to be involved in balancing the excessive $\mathrm{H}^{+}$production during nitrogen assimilation [131]. Moreover, it was reported that the aluminum-activated malate transporter in wheat, TaALMT1, promoted the acidification of an alkaline rhizosphere by facilitating the exudation of both malate and the zwitterionic buffer, gamma-aminobutyric acid (GABA) from the plant root [132]. The expression level of TaALMT1 was positively correlated with the growth performance of the wheat plant in the alkaline environment. The expression pattern of the amino acid transporter SICAT9 in Solanum lycopersicum was linked to the exchange of GABA for glutamate and aspartate during fruit ripening, and eventually led to changes in the amino acid composition of the developing fruit [131]. The result is a change in the flavor and the nutritional value of the fruit [131]. The correlation between GABA concentration and low cytosolic $\mathrm{pH}$ during the early stages of fruit development was demonstrated using nuclear magnetic resonance (NMR) [133]. It was suggested that the export of GABA out of the vacuole in exchange for the import of glutamate or aspartate could serve to counterbalance the proton charges through the 'reverse' GABA shunt pathway [131].

\subsection{Protons Are the Unneglectable Regulators of Active Transporters under Stresses}

The activities of active transporters have been reported to be $\mathrm{pH}$-dependent. Such property implies the regulation of the transporter activities at biological membranes be- 
tween various cellular compartments with different $\mathrm{pH}$. An obvious example is the increase in proline uptake by amino acid transporters when the extracellular $\mathrm{pH}$ was made to decrease [108]. In addition, the different $\mathrm{pH}$ of the vacuole, cytosol, and apoplast further implies the finetune of the transport direction to achieve different purposes. For example, the more acidic vacuole compared to the cytosol favors the storage of toxic nicotine in the vacuole [57] and the influx of $\mathrm{Cl}^{-}$into the vacuole for turgor regulation [67], while the acidification of the rhizosphere favors the exudation of malate and GABA from plant cells to the rhizosphere by TaALMT1 [132]. The $\mathrm{pH}$ dependence properties of active transporters even allow bidirectional transport $\mathrm{H}^{+}$. For example, AtSUC4 was demonstrated to have reversible direction of $\mathrm{H}^{+}$transport when the $\mathrm{H}^{+}$gradient between the membrane was made to reverse, although the structural basis of such reverse transport direction by the transporter has remained unclear [78]. Reverse transport direction has been observed in other transporters. The possible mechanisms underlying the reverse transport direction include the existence of two discrete conformation states of the transporter protein, which allows the binding of the substrate to either side of the transporter, and the existence of the substrate binding site, which is close to both sides of the transporter protein [134]. For example, based on the protein crystal structure, different conformations of BetP, a betaine transporter, were observed [135]. The existence of both the outward-facing conformation and the inward-facing conformation underlies the possibility of alternating access of the substrate [135]. In another study, it was reported that $\mathrm{Glt}_{\mathrm{ph}} \mathrm{H} 7$ has the substrate binding site close to both sides of the transporter to allow alternating access of glutamate from either side of the transporter [136]. However, the structural basis of the revere transport direction by the transporters discussed in this review has remained unknown. More mechanical and structural studies on the transporters will be needed to address this phenomenon.

The $\mathrm{pH}$ of different cellular compartments is highly regulated and yet highly dynamic, especially when under stress. The alteration in $\mathrm{pH}$ of different cellular compartments under stress implies the regulation of transporter activities. For example, under drought stress, the $\mathrm{pH}$ in xylem sap was found to be increased from 6.1 to 6.7 [47], which is closer to $\mathrm{pH} 7$, the optimal $\mathrm{pH}$ for the transport activity of AtDTX50 [46]. The significance of such $\mathrm{pH}$-dependent activity lies in the possibility of improving ABA transport activity under stress. In addition, under stress, the deprotonation of phytohormones such as auxin and ABA molecules highlights the necessity of active transporters when the diffusion across membranes is made more difficult. Such reliance on active transporters for phytohormone transportation allows a highly controlled transport of the phytohormones under stresses.

Considering the mechanics of the active transporters under stress, it could be deduced that the altered expression of the transporters under stresses could not fully explain the regulation on the transport capacities. In some cases, the altered transporter activity under stress could be coupled with the altered expression of the gene encoding the transporter to improve the transport efficiency. For example, the pathogen-induced expression of EDS5 is coupled with possible pathogen-induced cytosolic acidification [5,48,51], which favors the SA-exporting activity of EDS5. However, in some cases, the expression of transporters could not sufficiently explain the altered substrate transport under stress. For example, it was found that photosynthetic rate, light level, and $\mathrm{CO}_{2}$ concentration had limited effects on the expressions of SUTs [86]. However, an improved sucrose transport upon the increased photosynthetic rate is expected. In this case, the possible alteration of the sucrose transport efficiency could be the explanation. It is therefore important to understand the mechanics of the active transporters under different situations when the cellular $\mathrm{pH}$ fluctuates.

The modulation of the expression of active transporters in plants has been considered a common approach to modulate the accumulation of desired metabolites [137]. Since protons play important roles in regulating active transports in plants, attempts to modulate the transporter activities could be broadened to consider the manipulation of genes that regulate the proton levels in various cellular compartments. Such manipulation allows the finetune of transporter activities under stress when cellular $\mathrm{pH}$ fluctuates. 
The movement of $\mathrm{H}^{+}$across the biological membranes results in electrochemical proton gradient, which means the proton gradient as well as the electrical potential gradient across the membrane, to energize the substrate transport. In the above discussion, several proteins, such as AtEDS5 [48,51], AtSUC4 [78,79,81], and AtLHT1 [111,125], were reported to have their activities dependent on the proton gradient. Such observations are in line with the suggestion that the active transporters are energized by the electrochemical proton gradient across the biological membranes. In several examples, such as AtDTX50 [46], AtDTX33 [67], AtDTX35 [67], PvSUT1.1 [84], AtPLT5 [91], MdSTP13a [92], and HvProT [116], the transport activities were shown to be different under different $\mathrm{pH}$ of the vacuole/medium. However, it is not clear whether such differences of activities are merely a result of the altered electrochemical proton gradient across the membrane or a result of the structural change of the protein under different $\mathrm{pH}$. Detailed studies on the conformation of the proteins under different $\mathrm{pH}$ will be needed to address the question.

Examples of the activities, $\mathrm{pH}$ dependence, and the biological significance of $\mathrm{ABC}$ transporters, MATE transporters, MSTs, SUTs, and amino acid transporters are summarized in Table 1.

Table 1. Examples of the activities, $\mathrm{pH}$ dependence, and the biological significance of ATP-binding cassette $(\mathrm{ABC})$ transporters, multidrug and toxic compound extrusion (MATE) transporters, monosaccharide transporters (MSTs), sucrose transporters (SUTs), and amino acid transporters.

\begin{tabular}{|c|c|c|c|c|c|}
\hline $\begin{array}{l}\text { Transporter } \\
\text { Type }\end{array}$ & $\begin{array}{l}\text { Transporter } \\
\text { Name }\end{array}$ & Transport Activity & pH Dependence & Biological Significance & References \\
\hline \multirow{5}{*}{ MATE } & Nt-JAT1 & $\begin{array}{l}\text { Mediates nicotine influx } \\
\text { into the vacuole }\end{array}$ & $\begin{array}{c}\text { Makes use of } \mathrm{pH} \\
\text { gradient across vacuolar } \\
\text { membrane, with } \mathrm{pH} \\
\text { inside vacuole lower than } \\
\text { in cytosol }\end{array}$ & Storage of toxic compound & [57] \\
\hline & AtDTX50 & $\begin{array}{l}\text { Mediates ABA efflux } \\
\text { under drought stress }\end{array}$ & $\begin{array}{l}\text { Most active at } \mathrm{pH} 7 \text { when } \\
\text { compared among } \mathrm{pH} 6,7, \\
\text { and } 8\end{array}$ & $\begin{array}{l}\text { Promotes ABA efflux } \\
\text { under drought stress when } \\
\text { the pH of the xylem sap } \\
\text { becomes closer to neutral }\end{array}$ & [46] \\
\hline & AtDTX33 & $\begin{array}{l}\text { Mediates } \mathrm{Cl}^{-} \text {influx into } \\
\text { vacuoles; mutant impaired } \\
\text { in stomatal opening }\end{array}$ & $\begin{array}{l}\text { Most active at vacuolar } \\
\text { pH } 5 \text { when compared } \\
\text { among vacuolar pH 5, } 6, \\
\text { and } 7\end{array}$ & $\begin{array}{l}\text { Promotes } \mathrm{Cl}^{-} \text {influx into } \\
\text { the vacuole, which is more } \\
\text { acid than the cytosol, for } \\
\text { turgor regulation }\end{array}$ & [67] \\
\hline & AtDTX35 & $\begin{array}{l}\text { Mediates } \mathrm{Cl}^{-} \text {influx into } \\
\text { vacuoles; mutant impaired } \\
\text { in stomatal opening }\end{array}$ & $\begin{array}{l}\text { Most active at vacuolar } \\
\text { pH } 5 \text { when compared } \\
\text { among vacuolar pH 5, } 6, \\
\text { and } 7\end{array}$ & $\begin{array}{l}\text { Promotes } \mathrm{Cl}^{-} \text {influx into } \\
\text { the vacuole, which is more } \\
\text { acid than the cytosol, for } \\
\text { turgor regulation }\end{array}$ & [67] \\
\hline & AtEDS5 & $\begin{array}{l}\text { Mediates SA efflux from } \\
\text { chloroplast to cytoplasm }\end{array}$ & $\begin{array}{l}\text { The transport activity is } \\
\text { driven by the proton } \\
\text { gradient across the } \\
\text { biological membrane }\end{array}$ & $\begin{array}{l}\text { The efflux of SA from } \\
\text { chloroplast to cytosol } \\
\text { promotes stress tolerance }\end{array}$ & {$[48,51]$} \\
\hline SUC & AtSUC4 & $\begin{array}{l}\text { Mediates vacuolar sucrose } \\
\text { storage }\end{array}$ & $\begin{array}{l}\text { Acts as a } \mathrm{H}^{+} / \text {sucrose } \\
\text { antiporter or symporter } \\
\text { depending on the } \mathrm{pH} \\
\text { difference between } \\
\text { vacuole lumen and the } \\
\text { medium outside }\end{array}$ & $\begin{array}{l}\text { Facilitates sugar } \\
\text { distribution under stress; } \\
\text { compared to the wild-type, } \\
\text { mutants have higher and } \\
\text { lower sucrose, fructose and } \\
\text { glucose in shoots and roots, } \\
\text { respectively, and are more } \\
\text { sensitive to salt, osmotic, } \\
\text { cold and ABA treatments }\end{array}$ & {$[78,79,81]$} \\
\hline
\end{tabular}


Table 1. Cont.

\begin{tabular}{|c|c|c|c|c|c|}
\hline $\begin{array}{l}\text { Transporter } \\
\text { Type }\end{array}$ & $\begin{array}{l}\text { Transporter } \\
\text { Name }\end{array}$ & Transport Activity & pH Dependence & Biological Significance & References \\
\hline & PvSUT1.1 & $\begin{array}{l}\text { Exports sucrose from leaf } \\
\text { through phloem }\end{array}$ & $\begin{array}{l}\text { Higher activity at lower } \\
\text { pH in medium }\end{array}$ & $\begin{array}{l}\text { Involved in sucrose } \\
\text { translocation between } \\
\text { different tissues of plant, } \\
\text { the downregulated } \\
\text { expression is possibly } \\
\text { associated with the heat } \\
\text { susceptibility of the plant }\end{array}$ & {$[84]$} \\
\hline \multirow{4}{*}{ MST } & AtPLT5 & $\begin{array}{l}\text { Mediates transport of a } \\
\text { large spectrum of polyols }\end{array}$ & $\begin{array}{l}\text { Maximal transport } \\
\text { activity at } \mathrm{pH} 5.5 \text {; activity } \\
\text { reduced at } \mathrm{pH} 6.5 \text { and no } \\
\text { activity at } \mathrm{pH} 7\end{array}$ & $\begin{array}{l}\text { Proposed to be involved in } \\
\text { the retrieval of sugars from } \\
\text { the apoplast }\end{array}$ & [91] \\
\hline & MdSTP13a & $\begin{array}{l}\text { Mediates transport of a } \\
\text { hexose and sucrose for } \\
\text { pollen tube growth }\end{array}$ & $\begin{array}{l}\text { Optimal uptake at } \mathrm{pH} 6 \\
\text { in yeast model }\end{array}$ & Growth and development & [92] \\
\hline & AtSTP1 & $\begin{array}{l}\text { Inducible by salinity but } \\
\text { mainly involved in the } \\
\text { distribution of } \\
\text { monosaccharides under } \\
\text { normal conditions; } \\
\text { mutant with reduced } \\
\text { ability to uptake glucose, } \\
\text { fructose and galactose }\end{array}$ & unknown & $\begin{array}{l}\text { Growth and development, } \\
\text { adaptation to the } \\
\text { environment }\end{array}$ & [94] \\
\hline & AtSTP13 & $\begin{array}{l}\text { Inducible by salinity and } \\
\text { ABA treatments; involved } \\
\text { in the reabsorption of } \\
\text { monosaccharides leaked } \\
\text { from damaged cells; } \\
\text { mutant with reduced } \\
\text { ability to uptake glucose, } \\
\text { fructose and galactose }\end{array}$ & unknown & $\begin{array}{l}\text { Growth and development, } \\
\text { adaptation to the } \\
\text { environment }\end{array}$ & [94] \\
\hline ATF & HvProT & $\begin{array}{l}\text { Proline transportation } \\
\text { during salt stress }\end{array}$ & $\begin{array}{c}\text { pH-dependent; the } \\
\text { proline uptake activity o } \\
\text { yeast mutant } \\
\text { complemented with } \\
\text { HvProT was the highest } \\
\text { at pH } 4.5 \text { among pH } 4.5, \\
5.5 \text {, and } 6.5\end{array}$ & $\begin{array}{l}\text { Adaptation to the } \\
\text { environment }\end{array}$ & [116] \\
\hline $\mathrm{AAP}$ & AtLHT1 & $\begin{array}{l}\text { Transports a broad } \\
\text { spectrum of amino acids; } \\
\text { knockout mutant with } \\
\text { reduced susceptibility to } P \text {. } \\
\text { syringae; suspected to be } \\
\text { involved in SA pathway }\end{array}$ & $\mathrm{pH}$ gradient dependent & Resistance to biotic stress & {$[111,125]$} \\
\hline \multirow[t]{2}{*}{ APC } & AtCAT1 & $\begin{array}{l}\text { Lysine incorporation; } \\
\text { overexpressor more } \\
\text { resistant to P. syringae with } \\
\text { increased SA level in } \\
\text { leaves }\end{array}$ & unknown & Resistance to biotic stress & [126] \\
\hline & SICAT9 & $\begin{array}{l}\text { Exchange of GABA for } \\
\text { glutamate and aspartate } \\
\text { during fruit ripening }\end{array}$ & $\begin{array}{l}\text { The transport of GABA } \\
\text { has been suggested to } \\
\text { play a role in regulating } \\
\text { cytosolic pH }\end{array}$ & Growth and development & [131] \\
\hline
\end{tabular}


Table 1. Cont.

\begin{tabular}{|c|c|c|c|c|c|}
\hline $\begin{array}{l}\text { Transporter } \\
\text { Type }\end{array}$ & $\begin{array}{l}\text { Transporter } \\
\text { Name }\end{array}$ & Transport Activity & pH Dependence & Biological Significance & References \\
\hline \multirow{8}{*}{$\mathrm{ABC}$} & AtABCB1 & $\begin{array}{l}\text { Transports auxin; double } \\
\text { mutant with Atabcb19 } \\
\text { resulted in developmental } \\
\text { problem with poor fertility }\end{array}$ & unknown & Growth and development & {$[31]$} \\
\hline & AtABCB19 & $\begin{array}{l}\text { Transports auxin; double } \\
\text { mutant with Atabcb1 } \\
\text { resulted in developmental } \\
\text { problem with poor fertility }\end{array}$ & unknown & Growth and development & [31] \\
\hline & AtABCG25 & $\begin{array}{l}\text { Exports ABA; mutant with } \\
\text { ABA-sensitive phenotype } \\
\text { at early growth stage }\end{array}$ & unknown & $\begin{array}{l}\text { Adaptation to the } \\
\text { environment }\end{array}$ & [41] \\
\hline & AtABCG40 & $\begin{array}{c}\text { Uptakes ABA; mutant } \\
\text { with slow uptake of ABA } \\
\text { and insensitivity towards } \\
\text { ABA }\end{array}$ & unknown & $\begin{array}{l}\text { Adaptation to the } \\
\text { environment }\end{array}$ & [42] \\
\hline & CjMDR1 & $\begin{array}{l}\text { Transports berberine from } \\
\text { root to rhizome }\end{array}$ & unknown & $\begin{array}{l}\text { Adaptation to the } \\
\text { environment }\end{array}$ & [56] \\
\hline & Lr34 & $\begin{array}{l}\text { Transports ABA; ectopic } \\
\text { expression in wheat } \\
\text { enhanced the tolerance to } \\
\text { rice blast }\end{array}$ & unknown & $\begin{array}{l}\text { Adaptation to the } \\
\text { environment }\end{array}$ & [43] \\
\hline & AtABCC1 & $\begin{array}{l}\text { Mediates microsomal } \\
\text { uptake of PC and PC } \\
\text { conjugates for heavy metal } \\
\text { detoxification in vacuole }\end{array}$ & unknown & $\begin{array}{l}\text { Adaptation to the } \\
\text { environment }\end{array}$ & [26] \\
\hline & AtABCC2 & $\begin{array}{c}\text { Mediates microsomal } \\
\text { uptake of PC and PC } \\
\text { conjugates for heavy metal } \\
\text { detoxification in vacuole }\end{array}$ & unknown & $\begin{array}{l}\text { Adaptation to the } \\
\text { environment }\end{array}$ & [26] \\
\hline
\end{tabular}

\section{Conclusions}

ABC transporters, MATE transporters, MSTs, SUTs, and amino acid transporters are involved in the transport of ions, toxic compounds, sugars, hormones, and amino acids. The transport of these molecules is important in the growth, development, and stress adaptations of plants. Since these transporters are driven by proton motive force, the activities of these transporters are highly regulated by cellular $\mathrm{pH}$, which is usually influenced by both abiotic and biotic stresses. Besides directly participating in the transport activity by providing the proton motive force, $\mathrm{pH}$ also influences the charges of the substrates to be transported. In addition, the $\mathrm{pH}$ itself could possibly affect the transporter function. These factors together affect the transport efficiency. The role of the proton in molecular transports deserves more attention than it has received thus far. In-depth structural and mechanical studies will be needed to delineate the effects of $\mathrm{pH}$, proton gradient, and electrical potential gradient on the transporter functions.

Author Contributions: Y.-S.K. put together the first complete draft and prepared the final version. H.-M.L. planned and coordinated the writing and prepared the final version. Y.-S.K., S.-S.C., M.-S.N., G.C. and H.-M.L. contributed to the search of the literature and writing. All authors have read and agreed to the published version of the manuscript.

Funding: This work was supported by grants from the Hong Kong Research Grants Council: General Research Fund (14143916) and Area of Excellence Scheme (AoE/M-403/16). 
Institutional Review Board Statement: Not applicable.

Informed Consent Statement: Not applicable.

Data Availability Statement: Not applicable.

Acknowledgments: Jee-Yan Chu copy-edited the manuscript. Any opinions, findings, conclusions or recommendations expressed in this publication do not reflect the views of the Government of the Hong Kong Special Administrative Region or the Innovation and Technology Commission.

Conflicts of Interest: Authors declare no conflict of interest.

\section{References}

1. Bañó-Polo, M.; Baeza-Delgado, C.; Orzáez, M.; Marti-Renom, M.A.; Abad, C.; Mingarro, I. Polar/ionizable residues in transmembrane segments: Effects on helix-helix packing. PLOS ONE 2012, 7, e44263. [CrossRef] [PubMed]

2. Van Lehn, R.C.; Zhang, B.; Miller, T.F. Regulation of multispanning membrane protein topology via post-translational annealing. Elife 2015, 4, e08697. [CrossRef] [PubMed]

3. Wilkinson, S. PH as a stress signal. Plant Growth Regul. 1999, 29, 87-99. [CrossRef]

4. Kader, M.A.; Lindberg, S. Cytosolic calcium and pH signaling in plants under salinity stress. Plant Signal. Behav. 2010, 5, 233-238. [CrossRef]

5. Li, J.; Staiger, C.J. Understanding cytoskeletal dynamics during the plant immune response. Annu. Rev. Phytopathol. 2018, 56, 513-533. [CrossRef]

6. Cosse, M.; Seidel, T. Plant proton pumps and cytosolic pH-homeostasis. Front. Plant Sci. 2021, 12, 672873. [CrossRef]

7. Morsomme, P.; Boutry, M. The plant plasma membrane $\mathrm{H}^{+}$-ATPase: Structure, function and regulation. Biochim. Biophys. Acta (BBA)-Biomembr. 2000, 1465, 1-16. [CrossRef]

8. Bassil, E.; Coku, A.; Blumwald, E. Cellular ion homeostasis: Emerging roles of intracellular NHX $\mathrm{Na}^{+} / \mathrm{H}^{+}$antiporters in plant growth and development. J. Exp. Bot. 2012, 63, 5727-5740. [CrossRef]

9. Sze, H.; Li, X.; Palmgren, M.G.; Sze, H.; Li, X.; Palmgrenb, M.G. Energization of plant cell membranes by $\mathrm{H}^{+}$-pumping ATPases: Regulation and biosynthesis. Plant Cell 1999, 11, 677-689.

10. Haruta, M.; Gray, W.M.; Sussman, M.R. Regulation of the plasma membrane proton pump (H+-ATPase) by phosphorylation. Curr. Opin. Plant Biol. 2016, 28, 68-75. [CrossRef]

11. Janicka-Russak, M. Plant plasma membrane $\mathrm{H}^{+}$-ATPase in adaptation of plants to abiotic stresses. In Abiotic Stress Response in Plants-Physiological, Biochemical and Genetic Perspectives; Shanker, A., Venkatteswarlu, B., Eds.; Intech Open: London, UK, 2011.

12. Davies, J.M. Vacuolar energization: Pumps, shunts and stress. J. Exp. Bot. 1997, 48, 633-641. [CrossRef]

13. Ratajczak, R. Structure, function and regulation of the plant vacuolar $\mathrm{H}^{+}$-translocating ATPase. Biochim. Biophys. Acta (BBA)Biomembr. 2000, 1465, 17-36. [CrossRef]

14. Segami, S.; Asaoka, M.; Kinoshita, S.; Fukuda, M.; Nakanishi, Y.; Maeshima, M. Biochemical, structural and physiological characteristics of vacuolar $\mathrm{H}^{+}$-pyrophosphatase. Plant Cell Physiol. 2018, 59, 1300-1308. [CrossRef] [PubMed]

15. Park, J.; Lee, Y.; Martinoia, E.; Geisler, M. Plant hormone transporters: What we know and what we would like to know. BMC Biol. 2017, 15, 93. [CrossRef] [PubMed]

16. Henikoff, S.; Greene, E.A.; Pietrokovski, S.; Bork, P.; Attwood, T.K.; Hood, L. Gene families: The taxonomy of protein paralogs and chimeras. Science 1997, 278, 5338. [CrossRef] [PubMed]

17. Wilkens, S. Structure and mechanism of ABC transporters. F1000Prime Rep. 2015, 7, 14. [CrossRef] [PubMed]

18. Lane, T.S.; Rempe, C.S.; Davitt, J.; Staton, M.E.; Peng, Y.; Soltis, D.E.; Melkonian, M.; Deyholos, M.; Leebens-Mack, J.H.; Chase, M.; et al. Diversity of $\mathrm{ABC}$ transporter genes across the plant kingdom and their potential utility in biotechnology. BMC Biotechnol. 2016, 16, 47. [CrossRef]

19. Martinola, E.; Grill, E.; Tommaslnl, R.; Kreuz, K.; Amrhein, N. ATP-dependent glutathione S-conjugate "export" pump in the vacuolar membrane of plants. Nature 1993, 364, 247-249. [CrossRef]

20. Do, T.H.T.; Martinoia, E.; Lee, Y. Functions of ABC transporters in plant growth and development. Curr. Opin. Plant Biol. 2018, 41, 32-38. [CrossRef]

21. Hwang, J.; Song, W.; Hong, D.; Ko, D.; Yamaoka, Y.; Jang, S.; Yim, S.; Lee, E.; Khare, D.; Kim, K.; et al. Plant ABC transporters enable many unique aspects of a terrestrial plant's lifestyle. Mol. Plant 2016, 9, 338-355. [CrossRef]

22. Ha, T.; Do, T.; Choi, H.; Palmgren, M.; Martinoia, E.; Hwang, J.-U.; Lee, Y. Arabidopsis ABCG28 is required for the apical accumulation of reactive oxygen species in growing pollen tubes. Proc. Natl. Acad. Sci. USA 2019, 116, 25.

23. Footitt, S.; Slocombe, S.P.; Larner, V.; Kurup, S.; Wu, Y.; Larson, T.; Graham, I.; Baker, A.; Holdsworth, M. Control of germination and lipid mobilization by COMATOSE, the Arabidopsis homologue of human ALDP. EMBO J. 2002, 21, 2912-2922. [CrossRef] [PubMed]

24. Kunz, H.-H.; Scharnewski, M.; Feussner, K.; Feussner, I.; Flügge, U.-I.; Fulda, M.; Gierth, M. The ABC transporter PXA1 and peroxisomal $\beta$-oxidation are vital for metabolism in mature leaves of Arabidopsis during extended darkness. Plant Cell 2009, 21, 2733-2749. [CrossRef] 
25. Dahuja, A.; Kumar, R.R.; Sachdev, A.; Watts, A.; Singh, B.; Goswami, S.; Sachdev, A.; Praveen, S. Role of ATP-binding cassette transporters in maintaining plant homeostasis under abiotic and biotic stresses. Physiol. Plant. 2021, 785-801. [CrossRef] [PubMed]

26. Song, W.-Y.; Park, J.; Mendoza-Cózatl, D.G.; Suter-Grotemeyer, M.; Shim, D.; Hörtensteiner, S.; Geisler, M.; Weder, B.; Rea, P.A.; Rentsch, D.; et al. Arsenic tolerance in Arabidopsis is mediated by two ABCC-type phytochelatin transporters. Proc. Natl. Acad. Sci. USA 2010, 49, 21187-21192. [CrossRef] [PubMed]

27. von Voithenberg, L.V.; Park, J.; Stübe, R.; Lux, C.; Lee, Y.; Philippar, K. A novel prokaryote-type ECF/ABC transporter module in chloroplast metal hoemostasis. Front. Plant Sci. 2019, 10, 1264. [CrossRef] [PubMed]

28. Crouzet, J.; Roland, J.; Peeters, E.; Trombik, T.; Ducos, E.; Nader, J.; Boutry, M. NtPDR1, a plasma membrane ABC transporter from Nicotiana tabacum, is involved in diterpene transport. Plant Mol. Biol. 2013, 82, 181-192. [CrossRef] [PubMed]

29. Zažímalová, E.; Murphy, A.S.; Yang, H.; Hoyerová, K.; Hošek, P. Auxin transporters-Why so many? Cold Spring Harb. Perspect. Biol. 2010, 2, a001552.

30. Geisler, M. Getting to the right side. Plant Physiol. 2016, 172, 2081. [CrossRef] [PubMed]

31. Cecchetti, V.; Brunetti, P.; Napoli, N.; Fattorini, L.; Altamura, M.M.; Costantino, P.; Cardarelli, M. ABCB1 and ABCB19 auxin transporters have synergistic effects on early and late Arabidopsis anther development. J. Integr. Plant Biol. 2015, 57, 1089-1098. [CrossRef] [PubMed]

32. Noh, B.; Murphy, A.S.; Spalding, E.P. Multidrug Resistance-like genes of Arabidopsis required for auxin transport and auxinmediated development. Plant Cell 2001, 13, 2441-2454.

33. Yang, H.; Murphy, A.S. Functional expression and characterization of Arabidopsis ABCB, AUX 1 and PIN auxin transporters in Schizosaccharomyces pombe. Plant J. 2010, 59, 179-191. [CrossRef] [PubMed]

34. Chai, C.; Subudhi, P.K. Comprehensive analysis and expression profiling of the OsLAX and OsABCB auxin transporter gene families in rice (Oryza sativa) under phytohormone stimuli and abiotic stresses. Front. Plant Sci. 2016, 7, 593. [CrossRef] [PubMed]

35. Ribba, T.; Garrido-Vargas, F.; O'Brien, J.A. Auxin-mediated responses under salt stress: From developmental regulation to biotechnological applications. J. Exp. Biol. 2020, 71, 3843-3853. [CrossRef] [PubMed]

36. Ku, Y.-S.; Sintaha, M.; Cheung, M.-Y.; Lam, H.-M. Plant hormone signaling crosstalks between biotic and abiotic stress responses. Int. J. Mol. Sci. 2018, 19, 3206. [CrossRef] [PubMed]

37. Nambara, E.; Marion-Poll, A. Abscisic acid biosynthesis and catabolism. Annu. Rev. Plant Biol. 2005, 56, 165-185. [CrossRef]

38. Kuromori, T.; Sugimoto, E.; Shinozaki, K. Intertissue signal transfer of abscisic acid from vascular. Plant Physiol. 2014, 164, 1587-1592. [CrossRef] [PubMed]

39. Seo, M.; Koshiba, T. Transport of ABA from the site of biosynthesis to the site of action. J. Plant Res. 2011, 124, 501-507. [CrossRef] [PubMed]

40. Geilfus, C.-M. The $\mathrm{pH}$ of the apoplast: Dynamic factor with functional impact under stress. Mol. Plant 2017, 10, 1371-1386. [CrossRef] [PubMed]

41. Kuromori, T.; Miyaji, T.; Yabuuchi, H.; Shimizu, H.; Sugimoto, E.; Kamiya, A.; Moriyama, Y.; Shinozaki, K. ABC transporter AtABCG25 is involved in abscisic acid transport and responses. Proc. Natl. Acad. Sci. USA 2010, 107, 2361-2366. [CrossRef] [PubMed]

42. Kang, J.; Hwang, J.; Lee, M.; Kim, Y.-Y.; Assmann, S.M.; Martinoia, E.; Lee, Y. PDR-type ABC transporter mediates cellular uptake of the phytohormone abscisic acid. Proc. Natl. Acad. Sci. USA 2010, 107, 2355-2360. [CrossRef] [PubMed]

43. Krattinger, S.G.; Kang, J.; Bräunlich, S.; Boni, R.; Chauhan, H.; Selter, L.L.; Robinson, M.D.; Schmid, M.W.; Wiederhold, E.; Hensel, G.; et al. Abscisic acid is a substrate of the ABC transporter encoded by the durable wheat disease resistance gene Lr34. New Phytol. 2019, 223, 853-866. [CrossRef] [PubMed]

44. Omote, H.; Hiasa, M.; Matsumoto, T.; Otsuka, M.; Moriyama, Y. The MATE proteins as fundamental transporters of metabolic and xenobiotic organic cations. Trends Pharmacol. Sci. 2006, 27, 11. [CrossRef] [PubMed]

45. Takanashi, K.; Shitan, N.; Yazaki, K. The multidrug and toxic compound extrusion (MATE) family in plants. Plant Biotechnol. 2014, 31, 417-430. [CrossRef]

46. Zhang, H.; Zhu, H.; Pan, Y.; Yu, Y.; Luan, S.; Li, L. A DTX/MATE-type transporter facilitates abscisic acid efflux and modulates ABA sensitivity and drought tolerance in Arabidopsis. Mol. Plant 2014, 7, 1522-1532. [CrossRef] [PubMed]

47. Wilkinson, S.; Davies, W.J. Xylem sap pH increase: A drought signal received at the apoplastic face of the guard cell that involves the suppression of saturable abscisic acid uptake by the epidermal Symplast. Plant Physiol. 1997, 113, 559-573. [CrossRef] [PubMed]

48. Serrano, M.; Wang, B.; Aryal, B.; Garcion, C.; Abou-Mansour, E.; Heck, S.; Geisler, M.; Mauch, F.; Nawrath, C.; Métraux, J.-P. Export of salicylic acid from the chloroplast requires the multidrug and toxin extrusion-like transporter EDS5. Plant Physiol. 2013, 162, 1815-1821. [CrossRef]

49. Nawrath, C.; Métraux, J.-P. Salicylic acid induction-deficient mutants of Arabidopsis express PR-2 and PR-5 and accumulate high levels of camalexin after pathogen inoculation. Plant Cell 1999, 11, 1393-1404. [PubMed]

50. Lefevere, H.; Bauters, L.; Gheysen, G. Salicylic acid biosynthesis in plants. Front. Plant Sci. 2020, 11, 338. [CrossRef] [PubMed]

51. Nawrath, C.; Heck, S.; Parinthawong, N.; Métraux, J.-P. EDS5, an essential component of salicylic acid-dependent signaling for disease resistance in Arabidopsis, is a member of the MATE transporter family. Plant Cell 2002, 14, 275-286. [CrossRef] 
52. Coleman, J.; Blake-Kalff, M.; Davies, T.G.E. Detoxification of xenobiotics by plants: Chemical modification and vacuolar compartmentation. Trends Plant Sci. 1997, 2, 144-151. [CrossRef]

53. Hall, J.L. Cellular mechanisms for heavy metal detoxification and tolerance. J. Exp. Biol. 2002, 53, 1-11. [CrossRef]

54. Bennett, B.Y.R.N.; Wallsgrove, R.M. Secondary metabolites in plant defence mechanisms. New Phytol. 1994, 127, 617-633. [CrossRef]

55. Shitan, N. Secondary metabolites in plants: Transport and self-tolerance mechanisms. Biosci. Biotechnol. Biochem. 2016, 80, 1283-1293. [CrossRef]

56. Shitan, N.; Bazin, I.; Dan, K.; Obata, K.; Kigawa, K.; Ueda, K.; Sato, F.; Forestier, C.; Yazaki, K. Involvement of CjMDR1, a plant multidrug-resistance-type ATP-binding cassette protein, in alkaloid transport in Coptis japonica. Proc. Natl. Acad. Sci. USA 2003 100, 751-756. [CrossRef]

57. Morita, M.; Shitan, N.; Sawada, K.; Van Mongtagu, M.C.E.; Inzéc, D.; Rischer, H.; Goossens, A.; Oksman-caldentey, K.; Moriyama, Y.; Yazaki, K. Vacuolar transport of nicotine is mediated by a multidrug and toxic compound extrusion (MATE) transporter in Nicotiana tabacum. Proc. Natl. Acad. Sci. USA 2009, 106, 2447-2452. [CrossRef]

58. Park, J.; Song, W.-Y.; Ko, D.; Eom, Y.; Hansen, T.H.; Schiller, M.; Lee, T.G.; Martinoia, E.; Lee, Y. The phytochelatin transporters AtABCC1 and AtABCC2 mediate tolerance to cadmium and mercury. Plant J. 2012, 69, 278-288. [CrossRef]

59. Song, W.-Y.; Yamaki, T.; Yamaji, N.; Ko, D.; Jung, K.H.; Fujii-Kashino, M.; An, G.; Martinoia, E.; Lee, Y.; Ma, J.F. A rice ABC transporter, OsABCC1, reduces arsenic accumulation in the grain. Proc. Natl. Acad. Sci. USA 2014, 111, 15699-15704. [CrossRef]

60. Song, W.-Y.; Park, J.; Eisenach, C.; Maeshima, M.; Lee, Y.; Martinoia, E. ABC transporters and heavy metals. In Plant ABC Transporters; Geisler, M., Ed.; Springer International Publishing: Cham, Switzerland, 2014; pp. 1-17, ISBN 9783319065113.

61. Doshi, R.; Mcgrath, A.P.; Piñeros, M.; Szewczyk, P.; Garza, D.M.; Kochian, L.V.; Chang, G. Functional characterization and discovery of modulators of SbMATE, the agronomically important aluminium tolerance transporter from Sorghum bicolor. Sci. Rep. 2017, 7, 17996. [CrossRef]

62. Marinova, K.; Pourcel, L.; Weder, B.; Schwarz, M.; Barron, D.; Routaboul, J.-M.; Debeaujon, I.; Klein, M. The Arabidopsis MATE transporter TT12 acts as a vacuolar flavonoid $/ \mathrm{H}^{+}$- antiporter active in proanthocyanidin-accumulating cells of the seed coat. Plant Cell 2007, 19, 2023-2038. [CrossRef]

63. Durrett, T.P.; Gassmann, W.; Rogers, E.E. The FRD3-mediated efflux of citrate into the root vasculature is necessary for efficient iron translocation. Plant Physiol. 2007, 144, 197-205. [CrossRef] [PubMed]

64. Li, L.; He, Z.; Pandey, G.K.; Tsuchiya, T.; Luan, S. Functional cloning and characterization of a plant efflux carrier for multidrug and heavy metal detoxification. J. Biol. Chem. 2002, 277, 5360-5368. [CrossRef] [PubMed]

65. Zhang, J.; Wei, J.; Li, D.; Kong, X.; Rengel, Z.; Chen, L.; Yang, Y.; Cui, X.; Chen, Q. The role of the plasma membrane $\mathrm{H}^{+}$-ATPase in plant responses to aluminum toxicity. Front. Plant Sci. 2017, 8, 1757. [CrossRef] [PubMed]

66. Zhang, X.; Long, Y.; Huang, J.; Xia, J. Molecular mechanisms for coping with Al toxicity in plants. Int. J. Mol. Sci. 2019, 20 , 1551. [CrossRef]

67. Zhang, H.; Zhao, F.; Tang, R.; Yu, Y.; Song, J.; Wang, Y.; Li, L. Two tonoplast MATE proteins function as turgor-regulating chloride channels in Arabidopsis. Proc. Natl. Acad. Sci. USA 2017, 144, E2036-E2045. [CrossRef]

68. Misra, V.A.; Wafula, E.K.; Wang, Y.; DePamphilis, C.W.; Timko, M.P. Genome-wide identification of MST, SUT and SWEET family sugar transporters in root parasitic angiosperms and analysis of their expression during host parasitism. BMC Plant Biol. 2019, 19, 196. [CrossRef]

69. Doidy, J.; Vidal, U.; Lemoine, R. Sugar transporters in Fabaceae, featuring SUT MST and SWEET families of the model plant Medicago truncatula and the agricultural crop Pisum sativum. PLoS ONE 2019, 14, e0223173. [CrossRef]

70. Wang, Y.; Chen, Y.; Wei, Q.; Wan, H.; Sun, C. Phylogenetic relationships of sucrose transporters (SUTs) in plants and genome-wide characterization of SUT genes in Orchidaceae reveal roles in floral organ development. PeerJ 2021, 9, e11961. [CrossRef]

71. Drew, D.; North, R.A.; Nagarathinam, K.; Tanabe, M. Structures and general transport mechanisms by the major facilitator superfamily (MFS). Chem. Rev. 2021, 121, 5289-5335. [CrossRef]

72. Jeena, G.S.; Kumar, S.; Shukla, R.K. Structure, evolution and diverse physiological roles of SWEET sugar transporters in plants. Plant Mol. Biol. 2019, 100, 351-365. [CrossRef]

73. Eom, J.; Chen, L.; Sosso, D.; Julius, B.T.; Lin, I.W.; Qu, X.; Braun, D.M.; Frommer, W.B. SWEETs, transporters for intracellular and intercellular sugar translocation. Curr. Opin. Plant Biol. 2015, 25, 53-62. [CrossRef] [PubMed]

74. Lalonde, S.; Frommer, W.B. SUT sucrose and MST monosaccharide transporter inventory of the Selaginella genome. Front. Plant Sci. 2012, 3, 24. [CrossRef] [PubMed]

75. Lemoine, R.; La Camera, S.; Atanassova, R.; Dédaldéchamp, F.; Allario, T.; Pourtau, N.; Bonnemain, J.-L.; Laloi, M.; CoutosThévenot, P.; Maurousset, L.; et al. Source-to-sink transport of sugar and regulation by environmental factors. Front. Plant Sci. 2013, 4, 272. [CrossRef] [PubMed]

76. Nookaraju, A.; Upadhyaya, C.P.; Pandey, S.K.; Young, K.E.; Hong, S.J.; Park, S.K.; Park, S.W. Molecular approaches for enhancing sweetness in fruits and vegetables. Sci. Hortic. 2010, 127, 1-15. [CrossRef]

77. Julius, B.T.; Leach, K.A.; Tran, T.M.; Mertz, R.A.; Braun, D.M. Sugar transporters in plants: New insights and discoveries. Plant Cell Physiol. 2017, 58, 1442-1460. [CrossRef] 
78. Schulz, A.; Beyhl, D.; Marten, I.; Wormit, A.; Neuhaus, E.; Poschet, G.; Büttner, M.; Schneider, S.; Sauer, N.; Hedrich, R. Protondriven sucrose symport and antiport are provided by the vacuolar transporters SUC4 and TMT1/2. Plant J. 2011, 68, 129-136. [CrossRef]

79. Weise, A.; Barker, L.; Kühn, C.; Lalonde, S.; Buschmann, H.; Frommer, W.B.; Ward, J.M. A new subfamily of sucrose transporters, SUT4, with low affinity/high capacity localized in enucleate sieve elements of plants. Plant Cell 2000, 12, 1345-1355. [CrossRef]

80. Carpaneto, A.; Geiger, D.; Bamberg, E.; Sauer, N.; Fromm, J.; Hedrich, R. Phloem-localized, proton-coupled sucrose carrier ZmSUT1 mediates sucrose efflux under the control of the sucrose gradient and the proton motive force. J. Biol. Chem. 2005, 280, 21437-21443. [CrossRef]

81. Gong, X.; Liu, M.; Zhang, L.; Ruan, Y.; Ding, R.; Ji, Y.; Zhang, N.; Zhang, S.; Farmer, J.; Wang, C. Arabidopsis AtSUC2 and AtSUC4, encoding sucrose transporters, are required for abiotic stress tolerance in an ABA-dependent pathway. Physiol. Plant. 2015, 153, 119-136. [CrossRef]

82. Wang, D.; Liu, H.; Wang, H.; Zhang, P.; Shi, C. A novel sucrose transporter gene IbSUT4 involves in plant growth and response to abiotic stress through the ABF-dependent ABA signaling pathway in Sweetpotato. BMC Plant Biol. 2020, 20, 157. [CrossRef]

83. Gao, D.; Knight, M.R.; Trewavas, A.J.; Sattelmacher, B.; Plieth, C. Self-reporting Arabidopsis expressing $\mathrm{pH}$ and [Ca $\left.{ }^{2+}\right]$ indicators unveil ion dynamics in the cytoplasm and in the apoplast under abiotic stress. Plant Physiol. 2004, 134, 898-908. [CrossRef]

84. Santiago, J.P.; Ward, J.M.; Sharkey, T.D. Phaseolus vulgaris SUT1.1 is a high affinity sucrose-proton co-transporter. Plant Direct 2020, 4, e00260. [CrossRef]

85. Sharkey, T.D.; Zhang, R. High temperature effects on electron and proton circuits of photosynthesis. J. Integr. Plant Biol. 2010, 52, 712-722. [CrossRef]

86. Xu, Q.; Chen, S.; Yunjuan, R.; Chen, S.; Liesche, J. Regulation of sucrose transporters and phloem loading in response to environmental cues. Plant Physiol. 2018, 176, 930-945. [CrossRef]

87. Raghavendra, A.S.; Yin, Z.-H.; Heber, U. Light-dependent $\mathrm{pH}$ changes in leaves of C4 plants Comparison of the pH response to carbon dioxide and oxygen with that of C3 plants. Planta 1993, 189, 278-287. [CrossRef]

88. Slewinski, T.L. Diverse functional roles of monosaccharide transporters and their homologs in vascular plants: A physiological perspective. Mol. Plant 2011, 4, 641-662. [CrossRef]

89. Paulsen, P.A.; Custódio, T.F.; Pedersen, B.P. Crystal structure of the plant symporter STP10 illuminates sugar uptake mechanism in monosaccharide transporter superfamily. Nat. Commun. 2019, 10, 407. [CrossRef]

90. Bavnhøj, L.; Paulsen, P.A.; Flores-Canales, J.C.; Schiøtt, B.; Pedersen, B.P. Molecular mechanism of sugar transport in plants unveiled by structures of glucose $/ \mathrm{H}^{+}$symporter STP10. Nat. Plants 2021, 7, 1409-1419. [CrossRef]

91. Klepek, Y.; Geiger, D.; Stadler, R.; Klebl, F.; Landouar-arsivaud, L. Arabidopsis POLYOL TRANSPORTER5, a new member of the monosaccharide transporter-like superfamily, mediates $\mathrm{H}^{+}$-symport of numerous substrates, including myo-inositol, glycerol, and ribose. Plant Cell 2005, 17, 204-218. [CrossRef]

92. Li, C.; Meng, D.; Piñeros, M.A.; Mao, Y.; Dandekar, A.M.; Cheng, L. A sugar transporter takes up both hexose and sucrose for sorbitol-modulated in vitro pollen tube growth in apple. Plant Cell 2020, 32, 449-469. [CrossRef]

93. Schubert, M.; Koteyeva, N.K.; Wabnitz, P.W.; Santos, P.; Büttner, M.; Sauner, N.; Demchenko, K.; Pawlowski, K. Plasmodesmata distribution and sugar partitioning in nitrogen-fixing root nodules of Datisca glomerata. Planta 2011, 233, 139-152. [CrossRef]

94. Yamada, K.; Kanai, M.; Osakabe, Y.; Ohiraki, H.; Shinozaki, K.; Yamaguchi-Shinozaki, K. Monosaccharide absorption activity of Arabidopsis roots depends on expression profiles of transporter genes under high salinity conditions. J. Biol. Chem. 2011, 286, 43577-43586. [CrossRef]

95. Kong, W.; An, B.; Zhang, Y.; Yang, J.; Li, S.; Sun, T.; Li, Y. Sugar transporter proteins (STPs) in Gramineae crops: Comparative analysis, phylogeny, evolution, and expression profiling. Cells 2019, 8, 560. [CrossRef]

96. Muratore, C.; Espen, L.; Prinsi, B. Nitrogen uptake in plants: The plasma membrane root transport systems from a physiological and proteomic perspective. Plants 2021, 10, 681. [CrossRef]

97. Feng, H.; Fan, X.; Miller, A.J.; Xu, G. Plant nitrogen uptake and assimilation: Regulation of cellular pH homeostasis. J. Exp. Bot. 2020, 71, 4380-4392. [CrossRef]

98. Yao, X.; Nie, J.; Bai, R.; Sui, X. Amino acid transporters in plants: Identification and function. Plants 2020, 9, 972. [CrossRef]

99. Yang, G.; Wei, Q.; Huang, H.; Xia, J. Amino acid transporters in plant cells: A brief review. Plants 2020, 9, 967. [CrossRef]

100. Ortiz-Lopez, A.; Chang, H.-C.; Bush, D.R. Amino acid transporters in plants. Biochim. Biophys. Acta 2000, 1465, $275-280$. [CrossRef]

101. Okumoto, S.; Pilot, G. Amino acid export in plants: A missing link in nitrogen cycling. Mol. Plant 2011, 4, 453-463. [CrossRef]

102. Dinkeloo, K.; Boyd, S.; Pilot, G. Update on amino acid transporter functions and on possible amino acid sensing mechanisms in plants. Semin. Cell Dev. Biol. 2018, 74, 105-113. [CrossRef]

103. Jack, D.L.; Paulsen, I.T.; Saier, J. The amino acid/polyamine/organocation (APC) superfamily of transporters specific for amino acids, polyamines and organocations. Microbiology 2000, 146, 1797-1814. [CrossRef]

104. Young, G.B.; Jack, D.L.; Smith, D.W.; Saier, M.H., Jr. The amino acid/auxin: Proton symport permease family. Biochim. Biophys. Acta (BBA)-Biomembr. 1999, 1415, 306-322. [CrossRef]

105. Zhao, C.; Pratelli, R.; Yu, S.; Shelley, B.; Collakova, E.; Pilot, G. Detailed characterization of the UMAMIT proteins provides insight into their evolution, amino acid transport properties, and role in the plant. J. Exp. Bot. 2021, 72, 6400-6417. [CrossRef] 
106. Williams, L.E.; Nelson, S.J.; Hall, J.L. Characterization of solute transport in plasma membrane vesicles isolated from cotyledons of Ricinus communis L.-II. Evidence for a proton-coupled mechanism for sucrose and amino acid uptake. Planta 1990, 182, 540-545. [CrossRef]

107. Li, Z.C.; Bush, D.R. Structural determinants in substrate recognition by proton-amino acid symports in plasma membrane vesicles isolated from sugar beet leaves. Arch. Biochem. Biophys. 1992, 294, 519-526. [CrossRef]

108. Fischer, W.N.; Kwart, M.; Hummel, S.; Frommer, W.B. Substrate specificity and expression profile of amino acid transporters (AAPs) in Arabidopsis. J. Biol. Chem. 1995, 270, 16315-16320. [CrossRef]

109. Okumoto, S.; Koch, W.; Tegeder, M.; Fischer, W.N.; Biehl, A.; Leister, D.; Stierhof, Y.D.; Frommer, W.B. Root phloem-specific expression of the plasma membrane amino acid proton co-transporter AAP3. J. Exp. Bot. 2004, 55, 2155-2168. [CrossRef]

110. Montamat, F.; Maurousset, L.; Tegeder, M.; Frommer, W.; Delrot, S. Cloning and expression of amino acid transporters from broad bean. Plant Mol. Biol. 1999, 41, 259-268. [CrossRef]

111. Hirner, A.; Ladwig, F.; Stransky, H.; Okumoto, S.; Keinath, M.; Harms, A.; Frommer, W.B.; Koch, W. Arabidopsis LHT1 is a high-affinity transporter for cellular amino acid uptake in both root epidermis and leaf mesophyll. Plant Cell 2006, 18, 1931-1946. [CrossRef]

112. Rentsch, D.; Hirner, B.; Schmelzer, E.; Frommer, W.B. Salt stress-induced proline transporters and salt stress-repressed broad specificity amino acid permeases identified by suppression of a yeast amino acid permease-targeting mutant. Plant Cell 1996, 8 , 1437-1446.

113. Wang, J.J.; Hou, Q.Q.; Li, P.H.; Yang, L.; Sun, X.C.; Benedito, V.A.; Wen, J.Q.; Chen, B.B.; Mysore, K.S.; Zhao, J. Diverse functions of multidrug and toxin extrusion (MATE) transporters in citric acid efflux and metal homeostasis in Medicago truncatula. Plant J. 2017, 90, 79-95. [CrossRef]

114. Zhao, H.; Ma, H.; Yu, L.; Wang, X.; Zhao, J. Genome-wide survey and expression analysis of amino acid transporter gene family in rice (Oryza sativa L.). PLoS ONE 2012, 7, e49210. [CrossRef]

115. Wan, Y.; King, R.; Mitchell, R.A.C.; Hassani-Pak, K.; Hawkesford, M.J. Spatiotemporal expression patterns of wheat amino acid transporters reveal their putative roles in nitrogen transport and responses to abiotic stress. Sci. Rep. 2017, 7, 5461. [CrossRef]

116. Ueda, A.; Shi, W.; Sanmiya, K.; Shono, M.; Takabe, T. Functional analysis of salt-inducible proline transporter of barley roots. Plant Cell Physiol. 2001, 42, 1282-1289. [CrossRef]

117. Tian, R.; Yang, Y.; Chen, M. Genome-wide survey of the amino acid transporter gene family in wheat (Triticum aestivum L.): Identification, expression analysis and response to abiotic stress. Int. J. Biol. Macromol. 2020, 162, 1372-1387. [CrossRef]

118. Zheng, L.; Ma, S.; Zhou, T.; Yue, C.; Hua, Y.; Huang, J. Genome-wide identification of Brassicaceae B-BOX genes and molecular characterization of their transcriptional responses to various nutrient stresses in allotetraploid rapeseed. BMC Plant Biol. 2021, 21, 288. [CrossRef]

119. Yancey, P.H. Organic osmolytes as compatible, metabolic and counteracting cytoprotectants in high osmolarity and other stresses. J. Exp. Biol. 2005, 208, 2819-2830. [CrossRef]

120. El Moukhtari, A.; Cabassa-Hourton, C.; Farissi, M.; Savouré, A. How does proline treatment promote salt stress tolerance during crop plant development? Front. Plant Sci. 2020, 11, 1127. [CrossRef]

121. Ben Ahmed, C.; Magdich, S.; Ben Rouina, B.; Sensoy, S.; Boukhris, M.; Ben Abdullah, F. Exogenous proline effects on water relations and ions contents in leaves and roots of young olive. Amino Acids 2011, 40,565-573. [CrossRef]

122. Huang, Y.; Bie, Z.; Liu, Z.; Zhen, A.; Wang, W. Protective role of proline against salt stress is partially related to the improvement of water status and peroxidase enzyme activity in cucumber. Soil Sci. Plant Nutr. 2009, 55, 698-704. [CrossRef]

123. Lone, M.I.; Kueh, J.S.H.; Wyn Jones, R.G.; Bright, S.W.J. Influence of proline and glycinebetaine on salt tolerance of cultured barley embryos. J. Exp. Bot. 1987, 38, 479-490. [CrossRef]

124. Buell, C.R.; Joardar, V.; Lindeberg, M.; Selengut, J.; Paulsen, I.T.; Gwinn, M.L.; Dodson, R.J.; Deboy, R.T.; Durkin, A.S.; Kolonay, J.F.; et al. The complete genome sequence of the Arabidopsis and tomato pathogen Pseudomonas syringae pv. tomato DC3000. Proc. Natl. Acad. Sci. USA 2003, 100, 10181-10186. [CrossRef]

125. Liu, G.; Ji, Y.; Bhuiyan, N.H.; Pilot, G.; Selvaraj, G.; Zou, J.; Wei, Y. Amino acid homeostasis modulates salicylic acid-associated redox status and defense responses in Arabidopsis. Plant Cell 2010, 22, 3845-3863. [CrossRef]

126. Yang, H.; Postel, S.; Kemmerling, B.; Ludewig, U. Altered growth and improved resistance of Arabidopsis against Pseudomonas syringae by overexpression of the basic amino acid transporter AtCAT1. Plant Cell Environ. 2014, 37, 1404-1414. [CrossRef]

127. Song, J.T.; Lu, H.; Mcdowell, J.M.; Greenberg, J.T. A key role for ALD1 in activation of local and systemic defenses in Arabidopsis. Plant J. 2004, 40, 200-212. [CrossRef]

128. Song, J.T.; Lu, H.; Greenberg, J.T. Divergent roles in Arabidopsis thaliana development and defense of two homologous genes, Aberrant Growth and Death2 and Agd2-Like Defense Response Protein1, encoding novel aminotransferases. Plant Cell 2004, 16, 353-366. [CrossRef]

129. Näsholm, T.; Kielland, K.; Ganeteg, U. Uptake of organic nitrogen by plants. New Phytol. 2008, 182, 31-48. [CrossRef]

130. Raven, J.A.; Smith, F.A. Nitrogen assimilation and transport in vacuolar land plants in relation to intraceuular $\mathrm{pH}$ regulation. New Phytol. 1976, 76, 415-431. [CrossRef]

131. Snowden, C.J.; Thomas, B.; Baxter, C.J.; Smith, J.A.C.; Sweetlove, L.J. A tonoplast Glu/Asp/GABA exchanger that affects tomato fruit amino acid composition. Plant J. 2015, 81, 651-660. [CrossRef] 
132. Kamran, M.; Ramesh, S.A.; Gilliham, M.; Tyerman, S.D.; Bose, J. Role of TaALMT1 malate-GABA transporter in alkaline pH tolerance of wheat. Plant Cell Environ. 2020, 43, 2443-2459. [CrossRef]

133. Rolin, D.; Baldet, P.; Just, D.; Chevalier, C.; Biran, M.; Raymond, P. NMR study of low subcellular pH during the development of cherry tomato fruit. Aust. J. Plant Physiol. 2000, 27, 61-69.

134. Grewer, C.; Gameiro, A.; Zhang, Z.; Tao, Z.; Braams, S.; Rauen, T. Glutamate forward and reverse transport: From molecular mechanism to transporter-mediated release after ischemia. IUBMB Life 2008, 60, 609-619. [CrossRef]

135. Perez, C.; Koshy, C.; Yildiz, Ö.; Ziegler, C. Alternating-access mechanism in conformationally asymmetric trimers of the betaine transporter BetP. Nature 2012, 490, 126-130. [CrossRef]

136. Yernool, D.; Boudker, O.; Jin, Y.; Gouaux, E. Structure of a glutamate transporter homologue from Pyrococcus horikoshii. Nature 2004, 431, 811-818. [CrossRef]

137. Nogia, P.; Pati, P.K. Plant secondary metabolite transporters: Diversity, functionality, and their modulation. Front. Plant Sci. 2021, 12, 758202. [CrossRef] 